\title{
Probiotics, prebiotics and synbiotics: Safe options for next-generation therapeutics
}

\author{
Manoj Kumar Yadav ${ }^{1} \cdot$ Indu Kumari $^{1} \cdot$ Bijender Singh ${ }^{2,3} \cdot$ Krishna Kant Sharma $^{2} \cdot$ Santosh Kumar Tiwari ${ }^{1}$ (D)
}

Received: 1 July 2021 / Revised: 11 October 2021 / Accepted: 14 October 2021 / Published online: 11 January 2022

(C) Springer-Verlag GmbH Germany, part of Springer Nature 2021

\begin{abstract}
Probiotics have been considered as an economical and safe alternative for the treatment of a large number of chronic diseases and improvement of human health. They are known to modulate the host immunity and protect from several infectious and noninfectious diseases. The colonization, killing of pathogens and induction of host cells are few of the important probiotic attributes which affect several functions of the host. In addition, prebiotics and non-digestible food substances selectively promote the growth of probiotics and human health through nutrient enrichment, and modulation of gut microbiota and immune system. This review highlights the role of probiotics and prebiotics alone and in combination (synbiotics) in the modulation of immune system, treatment of infections, management of inflammatory bowel disease and cancer therapy.
\end{abstract}

\section{Key points}

- Probiotics and their derivatives against several human diseases.

- Prebiotics feed probiotics and induce several functions in the host.

- Discovery of novel and biosafe products needs attention for human health.

Keywords Probiotics $\cdot$ Prebiotics $\cdot$ Synbiotics $\cdot$ Human health $\cdot$ Chronic diseases

\section{Introduction}

Nature-derived products have been preferred over chemically synthesized compounds in food, medicine and human health (Bernardini et al. 2018). There have been adverse consequences on human health and environment due to the biased use of synthetic drugs, chemical-based preservatives and fertilizers. Looking at the present scenario, there is an urgent need for the discovery of novel, non-toxic and biosafe compounds for human health (Arnold 2013; Prestinaci et al. 2015; Trasande et al. 2018). Use of probiotics, their metabolites and prebiotics was previously considered as suitable alternative

Santosh Kumar Tiwari

santoshgenetics@mdurohtak.ac.in

1 Department of Genetics, Maharshi Dayanand University, Rohtak 124001, Haryana, India

2 Department of Microbiology, Maharshi Dayanand University, Rohtak 124001, Haryana, India

3 Department of Biotechnology, Central University of Haryana, Jant-Pali 123031, Mahendragarh, Haryana, India for the treatment of several infectious and non-infectious diseases (Markowiak and Śliżewska 2017; Silva et al. 2020). The recent reviews also focus on the role of probiotics against COVID-19 by boosting the host immunity and reducing pathogen interaction in the host. Further studies have also suggested promising benefits of probiotics in viral and other infections (Olaimat et al. 2020; Tiwari et al. 2020).

Probiotics are known to promote heath by stimulating native gut microbiota, host immunity, cholesterol reduction and several other functions, whereas their metabolites such as bacteriocins, lactic acid and hydrogen peroxide, also known as postbiotics, secreted by these microorganisms can be of immense importance as antimicrobials against a broad range of pathogenic bacteria (Silva et al. 2020). A relatively new form of product has been discovered to replace the live probiotics by inactivated or heat-killed probiotic cells known as paraprobiotics. It has shown potent applications for the treatment of several diseases including viral infections (Kanauchi et al. 2018). Prebiotics are generally food ingredients which not only promote the growth of probiotic microorganisms present in the human gut, but also stimulate the immune system. Moreover, use of fermented foods, the natural habitat of 
probiotic bacteria, is of immense importance which eventually helps in the better treatment of several diseases, including gutrelated disorders (Ahlawat et al. 2021). Thus, scientific use of probiotics, postbiotics, prebiotics, paraprobiotics and synbiotics can be safe and alternative strategy against microbial infections, particularly in the ongoing and post-pandemic situation. Therefore, there is need for the update of knowledge in this field to explore future possibilities for application of probiotics in human and animal diseases. Hence, this review may be considered as guidance to understand the naturederived probiotic products and their possible applications for the treatment/management of several human diseases including complications that arise during and/or after COVID-19 infection.

\section{Probiotics}

The history of probiotics began with early civilization when human started consuming fermented foods (Gogineni et al. 2013). Elie Metchnikoff suggested that health could be enhanced by manipulating the gut microbiome with good bacteria found in the yogurt. This became the concept of probiotics in medicine (Mackowiak 2013). Such microorganisms are able to modulate the gut microflora positively and reduce pathogenic bacteria releasing toxic compounds in human gut. In the past, several microorganisms have been used for the treatment of diseases which led to the origin of the term "probiotics" (Lee et al. 1999). Ferdinand Vergin in 1954 first time introduced the term "probiotics" in medical terminology in a paper "Anti-und Probiotika" (Sarowska et al. 2013). He also emphasized the adverse consequence of antibiotics on intestinal microflora as compared to good bacteria illustrating a positive effect on human health and referred as "probiotika" (Sarowska et al. 2013).

For the first time, a probiotic product was developed as drug for the treatment of infection caused by $E$. coli in pigs (Orrhage et al. 1994). Similarly, Mann and Spoerig (1974) revealed those people consuming yogurts fermented with Lactobacillus spp. were found to have low cholesterol level in blood. Thereafter, Harrison et al. (1974) observed the reduction of serum cholesterol in infants consuming Lactobacillus acidophilus. It has been convinced by World Health Organization (WHO) that probiotics are the nextmost significant immune defence system when commonly recommended antibiotics are ineffective against few microorganisms (Levy 2000; Parvez et al. 2006). Several intestinal bacteria such as Lactobacillus, Bifidobacterium and Enterococcus are beneficial and help in improving stability of gut microbiota. Probiotics are helpful for human health in several aspects such as antimicrobials, lactose intolerance, diarrheal diseases, ulcer treatment, immunity stimulation, food preservation, colon cancer and others (Masood et al. 2011).
There are several mechanisms known to explain the mode of action of probiotics against intestinal diseases. The colonization is one of the most efficient ways to initiate the probiotic efficacy of these bacteria. Furthermore, probiotics inhibit other pathogens by producing several inhibitory substances such as organic acids, short-chain fatty acids, carbon dioxide, hydrogen peroxide, acetaldehyde, acetoin, diacetyl, bacteriocins and bacteriocin-like inhibitory substances (Ammor et al. 2006; Tharmaraj and Shah 2009). Bacteriocins are ribosomally synthesized antimicrobial peptides or proteins produced by several bacteria exhibiting narrow to wide range of antimicrobial spectrum against pathogenic bacteria such as different species of Listeria, Clostridium, Staphylococcus, Bacillus and others (Dai et al. 2021; Fathizadeh et al. 2021). The bacteriocins of probiotic bacteria have gained importance due to their safe applications in foods, pharmaceuticals, veterinary and human medicines (Barcenilla et al. 2021; Liu et al. 2011; Sharma et al. 2021; Somashekaraiah et al. 2021). These are inhibitory to narrow and broad range of bacteria by reducing cell viability and affecting the metabolism of bacterial cells or toxin production (Chen et al. 2021; Sheoran and Tiwari 2019, 2020). Other mechanisms of probiotics action are competitive inhibition on intestinal epithelial surface by blocking the adhering sites of the intestinal epithelial surface and reduction in the pathogens interaction. Furthermore, the competition for nutrients is also considered as a mechanism for probiotic action. Interestingly, probiotics are known to inhibit the pathogens that consume the nutrients and deprive the host (Shim et al. 2016). The European Food Safety Authority (EFSA) has declared that several probiotic lactic acid bacteria (LAB) strains can be regarded to have "Qualified Presumption of Safety" QPS status (Korhonen 2010). Therefore, they are generally applied as starter culture for fermentations in the industries related with vegetables, cereals, dairy and meat-based products (Acuna et al. 2011).

\section{Prebiotics}

The term prebiotics is relatively new which is defined as "nondigestible food ingredients that beneficially affect the host by selectively stimulating the growth and/or activity of one or a limited number of bacteria in the colon for improving the host health" (Gibson and Roberfroid 1995). Recently, the definition of prebiotic has been reviewed by panel of experts from International Scientific Association for Probiotics and Prebiotics (ISAPP). The panel updated the definition in wider perspective as "a substrate that is selectively utilized by host microorganisms conferring a health benefit". This definition expands the concept of prebiotics to possibly include noncarbohydrate substances, applications to body sites other than the gastrointestinal tract and diverse categories other than food (Gibson et al. 2017). These are generally short-chain carbohydrates which escape digestion but used as substrates for the 
growth of probiotics in upper gastrointestinal tract (Roberfroid 2000; Cummings et al. 2001). Other compounds that are not classified as carbohydrates but are recommended to be prebiotics are cocoa-derived flavanols. In vivo and in vitro experiments demonstrate that flavanols can stimulate the growth of lactic acid bacteria (Tzounis et al. 2011). Prebiotics broadly occur in several plants such as onion, asparagus, garlic, chicory, Jerusalem artichoke, oat and wheat which induce the existing metabolic activities in the colon by stimulating bacterial growth in the gut (Cummings et al. 2001). It has been reported that there was a significant increase in faecal bifidobacterial population after consumption of fructooligosaccharides (Desai 2008; Louis et al. 2016). Prebiotics are generally not hydrolysed in the intestine, and they consist of low degrees of polymerization (2-20 units) in which monomers are generally glucose, galactose, fructose and/or xylose. Furthermore, they have caloric value due to non-digestion in the colon and have an energy contribution due to their involvement in fermentation (Roberfroid et al. 1993). The most commonly studied prebiotics include fructooligosaccharides (FOS), isomalto-oligosaccharides(IMO) and xylooligosaccharides (XOS).

FOS (inulin and neosugar) are beneficial dietary fibres which help to increase stool volume, relief in constipation and increase faecal acidity (Coussement 1996). Inulin is widely distributed in several plants and available in the market generally isolated from chicory roots, which is known to stimulate the growth of Bifidobacterium(Gibson et al. 1995). Neosugar, also known as meioligo, is enzymatically synthesized from sucrose by the transfructosylation activity of $\beta$ fructosidase of Aspergillus niger. Both are easily digested by bifidobacteria and other microbes, such as Enterococcus faecalis, E. faecium, Bacteroides vulgatus, B. thetaiotaomicron, B. ovatus, B. fragilis and Lactobacillus acidophilus(Desai 2008; Guarino et al. 2020).

IMO are found in fermented foods such as miso, soy sauce and honey and utilized by bifidobacteria and the Bacteroides groups (Kohmoto et al. 1988). IMO promotes the growth of Bifidobacterium and Lactobacillus spp. resulting in local and systemic Th-1-like immune response and regulation of immune function. Similar findings have been observed in the clinical trials (Yen et al. 2011). XOS are emerging prebiotics naturally found in fruits, bamboo shoots, vegetables, milk, honey, etc. (Aachary and Prapulla 2011; Vazquez et al. 2000). It has been reported that Bifidobacterium adolescentis can utilize XOS, whereas Lactococcus lactis, Lactobacillus rhamnosus and $L$. plantarum efficiently utilize oat $\beta$ glucooligosaccharides(Okazaki et al. 1990). Van Laere et al. (2000) have reported that the fermentation of arabino-XOS from wheat meal by bifidobacteria is due to the presence of xylanolytic enzyme systems, like xylosidase and a few arabinosidases. A $\beta$-D-xylosidase from Bifidobacterium breveK-110 and arabinosidases from $B$. adolescentis
DSM20083 (Van Laere et al. 2000) and B. breve(Shin et al. 2000) have been reported. Zeng et al. (2007) have studied $B$. infantis, B. adolescentis and B. bifidum and reported that all these species produced only xylosidase and arabinosidase, but no xylanase, $\alpha$-glucuronidase and acetyl xylan esterase activity was detected. Gullon et al. (2008) studied the fermentation of XOS from rice husks by several probiotic bacteria and found that growth of $B$. adolescentis CECT 5781 was higher in comparison to $B$. longum CECT 4503, B. breve CECT 4839 and $B$. infantis CECT 4551 in the presence of XOS.

The industrial development of prebiotics is on priority for improving the food quality and human health. Several functional foods containing prebiotics have been used to develop biscuits, candies, table-top sweetener, frozen yoghurt, etc. (Davani-Davari et al. 2019). Foods for specified health use (FOSHU) in Japan has used several prebiotics in specified food items, like lactulose, XOS, IMO, FOS, lactosucrose and oligosaccharides. Few other examples of prebiotic foods are yoghurts, cereals, fibre rich biscuits, cakes, sauces, powdered drinks, pasta, cereal bars, infant formula foods, breads and several fruit juices (Desai 2008).

\section{Synbiotics}

Synbiotics refer to mixture of prebiotics and probiotics for improvement of human or animal health (Markowiak and Śliżewska 2017). In synbiotic food products, probiotic bacteria selectively utilize the prebiotics as substrate for their growth (Perrin et al. 2001; Sharma and Shukla 2016). Recently, International Scientific Association for Probiotics and Prebiotics has updated the concept of synbiotics by panel of experts. According to them, synbiotics are two types, complementary and synergistic. A complementary synbiotic consists of a probiotic and a prebiotic that together confers one or more health benefits but do not require co-dependent functions. A synergistic synbiotic contains a substrate that is selectively utilized by co-administered microorganism(s) (Swanson et al. 2020). These guidelines will be helpful in future for understanding the relationship between pre- and probiotics and development of synbiotic products for health and therapeutic applications.

There are several reports available suggesting the synbiotic foods positively stimulate the host health and nutrition. It was observed that synbiotics not only increased the number of probiotic bacteria, Bifidobacterium and Lactobacillus in the faecal sample with concomitant reduction in coliform (Yang et al. 2005), but also increased the level of digestive enzymes such as lactase, lipase, sucrase and isomaltase in the test group. Recently, it has been reported that use of synbiotics has significantly decreased several cardiovascular risk factors, metabolic syndrome prevalence and markers of insulin resistance in elderly patients (Cicero et al. 2021). The ability of 
bifidobacteria to metabolize these prebiotics is a species-dependent, which is an important attribute for modulation of gut microbiota using specific prebiotics (Bielecka et al. 2002; Biedrzycka and Bielecka 2004). For example, $\beta$ fructofuranosidase from Bifidobacterium adolescentis G1 reacts with fructooligomers rather than inulin (Van der Meulen et al. 2004) and the same applies for B. bifidum also (Hartemink and Rombouts 1997). On the other hand, $B$. longum and $B$. animalis are able to hydrolyze wide range of FOS and XOS including inulin (Bruno et al. 2002). It has been reported that highest number of viable bifidobacteria are found in the food products (Bruno et al. 2002). Similarly, the viability of $B$. longum containing FOS is higher in curd. Probiotic $B$. lactis possesses $\beta$-glucosidase and $\beta$ fructofuranosidase to utilize oligosaccharides in fermented milk stimulating its growth and metabolism (MartinezVillaluenga and Gomez 2007; Semjonovs et al. 2004). Therapeutic potentials and health benefits of different probiotics, prebiotics and synbiotics have been depicted in Table 1.

\section{Health benefits and therapeutic potentials}

The importance of probiotics for human health has been established since long past. But study on the role of prebiotics, synbiotics and other derivatives is still at nascent stage. In this review, we have identified few complications/diseases where these products play significant role in the management/ treatment of such diseases. Looking at the current scenario of pandemics, the emphasis has been given on antimicrobial potential of probiotics against pathogenic microorganisms and host immunity. Interestingly, gut microbiota (GM) has been proposed as a "forgotten organ" which is tirelessly involved with other organs in establishing a bi- or multidirectional communications (Ahlawat et al. 2020b) is also discussed in addition to cancer. Therefore, the roles of probiotics in modulation of host immune system and gut microbiota, treatment of infection, inflammatory bowel diseases (IBD) and cancer have been elaborated. A schematic diagram showing the role of probiotics, prebiotics and synbiotics in different diseases is shown in Fig. 1.

\section{Probiotics and immunity}

Host immune system composes of different lymphoid and non-lymphoid cells along with humoral response. Intestinal lumen of mammals possesses secretory IgA (SIgA), which protects the intestinal epithelium from enteric pathogens and their toxins. SIgA removes antigens and pathogens from lumen of intestine by blocking their interaction with epithelial receptors and entangling them in mucus to remove via peristaltic movement and mucociliary activity. Secretory IgA production against specific mucosal antigens (pathogens) depends on the sampling by Peyer's patch M cells, processed by dendritic cells (antigen-presenting cells), T cell activation and finally in gut-associated lymphoid tissues (GALTs) and mesenteric lymph nodes (Brandtzaeg 2010). The intestinal stimulation for SIgA production depends upon multiple cytokines, including transforming growth factor- $\beta$, interleukin IL-4, IL5, IL-6 and IL-10 (Fig. 2). The sub-groups of cytokines, like transforming growth factor- $\beta$ and IL-10, are also needed to maintain mucosally induced tolerance. This substantiates the link between SIgA production, intestinal homeostasis and immunity (Mantis et al. 2011).

Furthermore, recent reports of COVID-19 patients showed significant increase of proinflammatory or anti-inflammatory cytokines, which includes $\mathrm{T}$ helper cytokines (type-1 and type-2), chemokines, galectins and tumour necrosis factor (TNF)-producing lymphocytes, interferon- $\gamma$, IL-2 and IL17(Ahlawat et al. 2020b; De Biasi et al. 2020). Therefore, blocking or regulating $\mathrm{T}$ cells and cytokines may be an effective therapeutic strategy, which can also reduce COVID-19 related deaths. It was found that selected probiotic LAB isolates showed reduction in the level of pro-inflammatory cytokines, TNF- $\alpha$, IL-1 $\beta$ and IL- 6 and inhibited the phosphorylation of Mitogen Activated Protein Kinases (MAPKs) in LPSstimulated RAW 264.7 cells (Khanna et al. 2020).

Probiotics modulate gut microbiota which ultimately induce the expression of several other genes involved in important intestinal functions, like immune modulation, postnatal intestinal maturation, nutrient absorption, mucosal barrier fortification, xenobiotic metabolism and angiogenesis (Mantis et al. 2011). The literature review and recent evidence suggest an axis between gut health and vital organs (Ahlawat et al. 2020a, b). Any alteration in gut microbiota and diversity affects immune modulation and may trigger gut disorders that eventually influences organ functioning. Furthermore, the interaction between intestinal SIgA protein and commensal gut bacteria involves Fab- and Fc-independent structural motifs, possessing bound secretory component (SC) as a complimentary partner (Mantis et al. 2011). Coating of commensal microorganisms with SIgA favours gut colonization and acclimatization of the mucosal immune system of newborn child towards antigens. Association of a Bifidobacterium or a Lactobacillus with non-specific SIgA enhances more than threefold higher probiotic adhesion to Caco-2 cells (human intestinal epithelial cells) as suggested by Mantis et al. (2011). Eventually, it leads to SIgA-affected epithelial permeability, signalling cascade for nuclear factor- $\mathrm{KB}$ translocation, pIgR production and induction of immune mediators.

Probiotics act as a primary factor in the progression of the postnatal immune system as well as oral tolerance and immunity. Several studies have proven the role of probiotics in stimulating and regulating the natural as well as acquired immunity (Isolauri et al. 2001). Probiotic-derived metabolite 
Table 1 Therapeutic potential and health benefits of probiotics, prebiotics and synbiotics

\begin{tabular}{|c|c|c|c|c|c|}
\hline $\begin{array}{l}\text { Biotic } \\
\text { types }\end{array}$ & Sources & Diseases & Health effects & Mechanism of action & References \\
\hline \multirow[t]{7}{*}{ Probiotics } & $\begin{array}{l}\text { Lactobacillus acidophilus } \\
\text { and Bifidobacterium } \\
\text { infantis }\end{array}$ & Intestinal infections & $\begin{array}{l}\text { Inhibition of } \\
\text { Staphylococcus aureus, } \\
\text { Salmonella } \\
\text { typhimurium, Yersinia } \\
\text { enterocolitica, } \\
\text { Clostridium perfringens } \\
\text { and Aeromonas } \\
\text { hydrophila }\end{array}$ & $\begin{array}{l}\text { Production of organic acids, } \\
\text { bacteriocins and other } \\
\text { primary metabolites, such as } \\
\text { hydrogen peroxide, carbon } \\
\text { dioxide and diacetyl }\end{array}$ & $\begin{array}{l}\text { (Laroia and Martin 1990; } \\
\text { Mishra and Lambert } \\
\text { 1996; Shahani and } \\
\text { Chandan 1979; Van der } \\
\text { Meer and } \\
\text { Bovee-Oudenhoven1998) }\end{array}$ \\
\hline & $\begin{array}{l}\text { L. casei, L. acidophilus and } \\
\text { B. bifidum }\end{array}$ & Immune enhancement & Data not available & $\begin{array}{l}\text { Enhancement in non-specific } \\
\text { (e.g. phagocyte function, NK } \\
\text { cell activity) and specific } \\
\text { (e.g. antibody and cytokine } \\
\text { production) host immune re- } \\
\text { sponses }\end{array}$ & $\begin{array}{l}\text { (Gill 1998; Kaila et al. 1992; } \\
\text { Schiffrin et al. 1995) }\end{array}$ \\
\hline & $\begin{array}{l}\text { L. acidophilus, } \\
\text { S. thermophilus, } \\
\text { B. longum, L. rhamnosus } \\
\text { GG and B. bifidum }\end{array}$ & Diarrhoeal infections & $\begin{array}{l}\text { Inhibitions of Escherichia } \\
\text { coli, Salmonella, } \\
\text { Shigella, Clostridium } \\
\text { difficile and rotavirus }\end{array}$ & $\begin{array}{l}\text { Production of organic acids, } \\
\text { bacteriocins, hydrogen } \\
\text { peroxide, carbon dioxide and } \\
\text { diacetyl }\end{array}$ & $\begin{array}{l}\text { (Barefoot and Klaenhammer } \\
\text { 1983; Hilton et al. 1997; } \\
\text { Merson et al. 1976; } \\
\text { Oksanen et al. 1990; } \\
\text { Siitonen et al. 1990; Tojo } \\
\text { et al. 1987) }\end{array}$ \\
\hline & $\begin{array}{l}\text { B. longum, L. casei Shirota, } \\
\text { L. acidophilus, } \\
\text { Bifidobaterium spp. and } \\
\text { L. rhamnosus GG }\end{array}$ & Cancer & $\begin{array}{l}\text { Inhibition of tumour } \\
\text { formation and } \\
\text { proliferation }\end{array}$ & $\begin{array}{l}\text { Inhibition of carcinogens } \\
\text { and/or procarcinogens, inhi- } \\
\text { bition of bacteria that con- } \\
\text { vert procarcinogens to } \\
\text { carcinogens, activation of } \\
\text { the host's immune system, } \\
\text { reduce the levels of faecal } \\
\text { enzymes responsible for } \\
\text { catalysing the conversion of } \\
\text { carcinogenic amines }\end{array}$ & $\begin{array}{l}\text { (Goldin et al. 1996; Lidbeck } \\
\text { et al. 1991; McIntosh } \\
\text { 1996; Morotomi 1996; } \\
\text { Reddy and Rivenson } \\
\text { 1993) }\end{array}$ \\
\hline & L. acidophilus & Hypercholesterolaemia & $\begin{array}{l}\text { Reduction of cholesterol } \\
\text { levels }\end{array}$ & $\begin{array}{l}\text { Assimilation of cholesterol and } \\
\text { deconjugation of bile salts }\end{array}$ & $\begin{array}{l}\text { (Buck and Gilliland 1994; } \\
\text { Gilliland and Speck 1977) }\end{array}$ \\
\hline & $\begin{array}{l}\text { L. acidophilus, } \\
\text { B. angulatum, B. breve, } \\
\text { B. Bifidum and B. longum }\end{array}$ & Lactose intolerance & Utilization of lactose & $\begin{array}{l}\text { Production of } \\
\beta \text {-D-galactosidase which } \\
\text { hydrolyze lactose }\end{array}$ & $\begin{array}{l}\text { (Hughes and Hoover 1995; } \\
\text { Kilara and Shahani 1976) }\end{array}$ \\
\hline & $\begin{array}{l}\text { L. acidophilus and } \\
\text { Bifidobacterium spp. }\end{array}$ & $\begin{array}{l}\text { Reduction of peptic } \\
\text { ulcer, } \\
\text { gastro-oesophageal }\end{array}$ & $\begin{array}{l}\text { Inhibition of Helicobacter } \\
\text { pylori }\end{array}$ & $\begin{array}{l}\text { Production of lactic and acetic } \\
\text { acids, bacteriocins etc }\end{array}$ & $\begin{array}{l}\text { (Berada et al. 1991; } \\
\text { Lankaputhra et al. 1996; } \\
\text { Lambert and Hull 1996) }\end{array}$ \\
\hline
\end{tabular}

L. rhamnosus GG Food allergy dyspepsia and gastric cancer
Prebiotics Inulin from chicory roots

Neosugar

Isomalto-oligosaccharides (IMO) from miso, soy sauce and honey

Xylooligosaccharides (XOS) Data not available from fruits, bamboo shoots, vegetables, honey, etc
Data not available

(1)

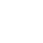

Data not available

Data not available 
Table 1 (continued)

\begin{tabular}{|c|c|c|c|c|c|}
\hline $\begin{array}{l}\text { Biotic } \\
\text { types }\end{array}$ & Sources & Diseases & Health effects & Mechanism of action & References \\
\hline & & & & $\begin{array}{l}\text { L. plantarum utilize oat } \\
\beta \text {-glucooligosaccharides }\end{array}$ & \\
\hline \multirow[t]{11}{*}{ Synbiotics } & $\begin{array}{l}\text { Food products containing } B \text {. } \\
\text { animalis and amylose corn } \\
\text { starch }\end{array}$ & Data not available & Data not available & $\begin{array}{l}\text { Promote the growth of } \\
\text { bifidobacteria }\end{array}$ & (Bruno et al. 2002) \\
\hline & $\begin{array}{l}\text { Curd containing } B \text {. longum } \\
\text { and fructooligosaccharide } \\
\text { (FOS) }\end{array}$ & Data not available & $\begin{array}{l}\text { Decrease cardiovascular } \\
\text { risk factors, metabolic } \\
\text { syndrome prevalence } \\
\text { and markers of insulin } \\
\text { resistance in elderly } \\
\text { patients }\end{array}$ & $\begin{array}{l}\text { Promote the growth of } \\
\text { B. longum }\end{array}$ & $\begin{array}{l}\text { (Cicero et al. 2021; Hughes } \\
\text { and Hoover 1995; Linares } \\
\text { et al. 2017) }\end{array}$ \\
\hline & $\begin{array}{l}\text { Oral synbiotic preparation } \\
\text { containing } L \text {. plantarum } \\
\text { and FOS }\end{array}$ & Sepsis in early infancy & $\begin{array}{l}\text { Significant reduction in } \\
\text { sepsis and lower } \\
\text { respiratory tract } \\
\text { infections }\end{array}$ & $\begin{array}{l}\text { Promotes growth of } \\
\text { L. plantarum ATCC202195 }\end{array}$ & (Panigrahi et al. 2017) \\
\hline & $\begin{array}{l}\text { Synbiotic containing five } \\
\text { probiotics (L. plantarum, } \\
\text { L. delbrueckii spp. } \\
\text { bulgaricus, } \\
\text { L. acidophilus, } \\
\text { L. rhamnosus, } \\
\text { Bifidobacterium bifidum) } \\
\text { and inulin }\end{array}$ & Data not available & Data not available & $\begin{array}{l}\text { Adult subjects with NASH } \\
\text { (non-alcoholic } \\
\text { steatohepatitis) demonstrat- } \\
\text { ed a significant reduction of } \\
\text { IHTG (intrahepatic triacyl- } \\
\text { glycerol) }\end{array}$ & (Wong et al. 2013) \\
\hline & $\begin{array}{l}\text { Synbiotic product containing } \\
\text { L. rhamnosus, } \\
\text { Bifidobacterium lactis, } \\
\text { inulin and oligofructose }\end{array}$ & Hepatic conditions & Data not available & $\begin{array}{l}\text { Increased level of intestinal } \\
\text { IgA, reduced blood } \\
\text { cholesterol levels and lower } \\
\text { blood pressure }\end{array}$ & $\begin{array}{r}\text { (Pathmakanthan et al. 2002; } \\
\text { Perez-Conesa et al. 2006) }\end{array}$ \\
\hline & $\begin{array}{l}\text { L. rhamnosus } \\
\text { CGMCC1.3724 and inulin }\end{array}$ & Obesity & Weight loss & $\begin{array}{l}\text { Reduction in leptin increase in } \\
\text { Lachnospiraceae }\end{array}$ & (Sanchez et al. 2014) \\
\hline & $\begin{array}{l}\text { L. acidophilus, } \\
\text { L. rhamnosus, B. bifidum, } \\
\text { B. longum, E. faecium and } \\
\text { FOS }\end{array}$ & Obesity & $\begin{array}{l}\text { Changes in anthropometric } \\
\text { measurements }\end{array}$ & $\begin{array}{l}\text { Decrease in TC, LDL-C and } \\
\text { total oxidative stress serum } \\
\text { levels }\end{array}$ & (Ipar et al. 2015) \\
\hline & L. sporogenes and inulin & Type 2 diabetes & Data not available & $\begin{array}{l}\text { Significant reduction in serum } \\
\text { insulin levels and } \\
\text { homeostatic model } \\
\text { assessment cell function }\end{array}$ & $\begin{array}{l}\text { (Tajadadi-Ebrahimi et al. } \\
\text { 2014) }\end{array}$ \\
\hline & $\begin{array}{l}\text { L. casei, L. rhamnosus, } \\
\text { S. thermophilus, B. breve, } \\
\text { L. acidophilus, B. longum, } \\
\text { L. bulgaricus and FOS }\end{array}$ & $\begin{array}{l}\text { Insulin resistance } \\
\text { syndrome }\end{array}$ & $\begin{array}{l}\text { The levels of fasting blood } \\
\text { sugar and insulin } \\
\text { resistance improved } \\
\text { significantly }\end{array}$ & Data not available & (Eslamparast et al. 2014) \\
\hline & $\begin{array}{l}\text { L. plantarum } \mathrm{La}-5 \text {, } \\
\text { B. animalis subsp. } \\
\text { lactisBB-12 and dietary } \\
\text { fibres }\end{array}$ & $\begin{array}{l}\text { Irritable bowel } \\
\text { syndrome }\end{array}$ & $\begin{array}{l}\text { Improvement in the IBS } \\
\text { score and satisfaction in } \\
\text { bowel movement } \\
\text { reported }\end{array}$ & Data not available & (Šmid et al. 2016) \\
\hline & $\begin{array}{l}\text { L. rhamnosus GG, B. lactis } \\
\text { Bb12 and inulin }\end{array}$ & Cancer & $\begin{array}{l}\text { Increase in probiotics in } \\
\text { stools and decrease in } \\
\text { Clostridium perfringens } \\
\text { led to increase in the IL2 } \\
\text { in polypectomised } \\
\text { patients }\end{array}$ & $\begin{array}{l}\text { Increased production of } \\
\text { interferon- } \Upsilon\end{array}$ & (Safavi et al. 2013) \\
\hline
\end{tabular}

(ascorbate) suggests its specific inhibitory effect on activated human $\mathrm{CD}^{+}{ }^{+}$effector $\mathrm{T}$ cells (Chang et al. 2019). Therefore, new trends in the marketing of food products have been inclined towards asserting health benefits from the consumption of microbe-derived metabolite, e.g. ascorbate (Chang et al. 2019).

The immunobalance of T-helper1/T-helper2 (Th1/Th2) plays a critical role in controlling autoimmune disorders
(Sicherer et al. 2004; Taylor and Hefle 2005). One theory of immunoregulation is based on homeostasis between Th1 and Th2 activities (Kidd 2003). Probiotics interact with DCs that resulted in the production of IL-12, which enhances Th1 cell proliferation, IFN- $\gamma$ production and polarization of naive Th cells (Tho) into Th1 type. IFN- $\gamma$ synthesis by Th1 cells inhibits Th2 cell proliferation and production of interleukin 4 (IL-4) that are responsible for allergic reactions. Cytokines 
play significant role in allergic responses as they are associated with patients having seasonal allergic responses (Ciprandi et al. 2004). IL-4 promotes the production of IgE by B lymphocytes. IFN- $\gamma$ promotes the differentiation of naïve Th lymphocytes (Tho) into Th1 and also inhibits proliferation of Th2 lymphocytes (Kadowaki 2007).

Mechanism of interaction of probiotics and immune cells has not been known fully so far. Cell wall components of bacteria are recognized by toll-like receptors (TLR) on the surface of DCs for maturation of DCs (Belkaid and Hand 2014). Lactobacilli may deliver signals to promote the activation of DCs (Mohamadzadeh et al. 2005). DCs are crucial for the induction of immune responses caused by bacterial colonization of the gut, and probiotics elicit these responses (Christensen et al. 2002). Changed gut microflora composition due to altered life styles and diets in developed and industrialized countries may be the cause for the higher prevalence of allergy (Bottcher et al. 2000). A model showing modulation of the immune system by probiotics is shown in Fig. 2 which explains enhanced expression of cell surface molecules on dendritic cells by probiotics. Additionally, the selected LAB enhanced the production of IL-12 which further enhances Th1 cell proliferation and IFN production. Thus, probiotics play significant role in modulation of immune system and protection against pathogens.

\section{Probiotics and COVID-19}

The ongoing pandemic has engulfed millions of lives on this planet due to complications developed by coronavirus disease 2019 (COVID-19). Unfortunately, even after implementing stringent public health measures globally, including social distancing, personnel care, mask wearing, lockdowns, etc., the disease has been spreading that leads to increase in number of infections and deaths all over the world. The main causative agent of this infection is severe acute respiratory syndrome coronavirus 2 (SARS-CoV-2), which is different from previously known coronaviruses. Therefore, available antivirals are not much effective (Singh and Rao 2021). Under these circumstances, nature-derived products such as probiotics and their derivatives may play significant roles in the prevention, treatment and management of ongoing pandemic (COVID19), post pandemic and other deadly infections.

To date, there is no evidence that probiotics directly inhibit coronaviruses. However, probiotic strains are known to inhibit several viruses as reviewed by our group and others recently (Kanauchi et al. 2018; Olaimat et al. 2020; Singh and Rao 2021; Tiwari et al. 2020). For example, in an animal study, it was found that $L$. plantarum UY inhibited the proliferation of influenza A (IFV) virus in the lung in a dose-dependent manner (Kawashima et al. 2011) and also stimulated Thelper cells type 1 (Th1) immune response resulting in higher synthesis of secretary IgA led to the removal of IFV from the lung. Thus, probiotic consumption not only decreases the viral loads but also increases immune response, which is critical requirement during these days of pandemics. As per available data, few strains of probiotics such as L. gasseri SBT2055, L. rhamnosus CRL1505, B. bifidum and B. subtilis need attention to explore their roles in the management of COVID19. In addition, probiotic bacteria also exhibit antioxidant activity, which is a unique opportunity for the management of COVID-19 because redox homeostasis is a pivotal in inhibiting disease progression (Starosila et al. 2017; Singh and Rao 2021).

Like other coronaviruses, SARS-CoV-2 binds with angiotensin converting enzyme 2 (ACE2) for internalization in target cells and utilize transmembrane protease serine 2 precursor (TMPRSS2) to prime and replicate in the infected organisms (Ahlawat et al. 2020a; Hoffmann et al. 2020). Therefore, researchers suggest that ACE inhibitors might play an important role in the management of COVID-19(Meng et al. 2020). It has been reported that several probiotics, particularly lactic acid bacteria are known to produce bioactive peptides as ACE inhibitor (Bhattacharya et al. 2021; Petrova et al. 2021). Furthermore, lung-gut axis and associated microbiota in relation with probiotics may be studied for the management of COVID-19 as described previously by Ahlawat et al. (2020a). Therefore, probiotics and their derivatives, alone and in combinations, showing potent activity need to be explored in the future.

\section{Probiotics and HIV infection}

Recent findings have supported the idea that probiotics can provide specific benefits to HIV infected patients during treatment by improving the microbiota and reducing inflammation (Anukam et al. 2008; d'Ettorre et al. 2015; Hummelen et al. 2011). However, few studies have shown the use of prebiotics and probiotics in HIV therapy, wherein prebiotics have modulated gut microbiota reconstruction with reduction in lipopolysaccharides (LPS) and CD14 levels and activation of $\mathrm{CD}^{+}$, $\mathrm{T}$ cells and NK cells (Gori et al. 2011; Monachese et al. 2011). Prebiotics are beneficial in modulating resident gut homeostasis and selectively promoting the growth of beneficial microorganisms with concomitant reduction in pathogenic gut bacteria responsible for opportunistic infections during HIV infection. Furthermore, they have also improved $\mathrm{CD}^{+}$, $\mathrm{T}$ cells counts and clinical GI symptoms (Hummelen et al. 2011; Irvine et al. 2011). Probiotics also regulate the intestinal epithelial barrier and reduce the HIV infection (Dai et al. 2012).

Children suffering from HIV infections have higher incidence of diarrhea and repeatedly experience malabsorption due to bacterial overgrowth. Positive effect on immune response occurs when L. plantarum $299 \mathrm{v}$ can be given to immune-compromised hosts. When one or more probiotics 


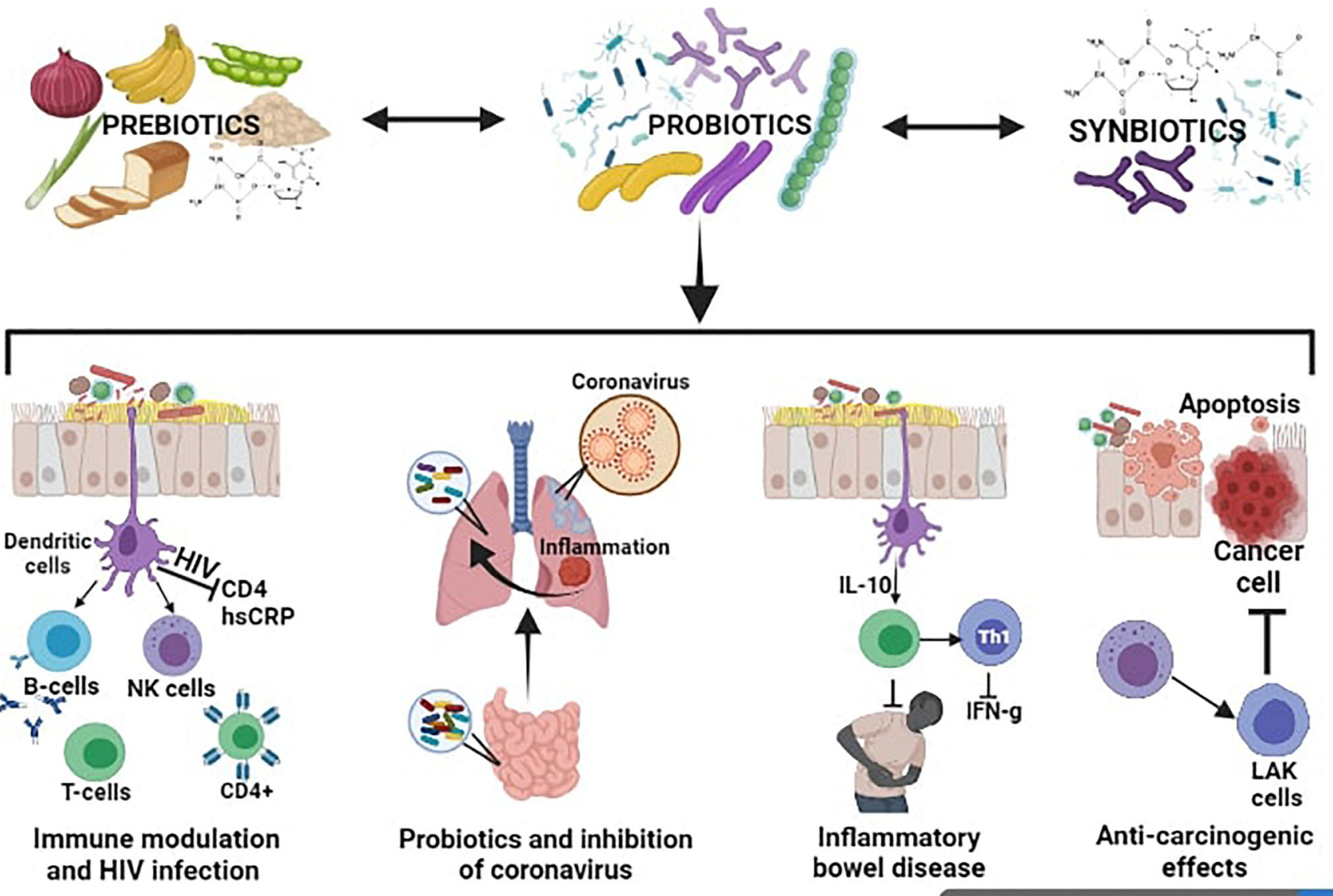

Created in BioRender.com bio

Fig. 1 A schematic diagram showing the potential roles of prebiotics, probiotics and synbiotics in immune modulation, inhibition of HIV and coronaviruses, inflammatory bowel diseases and cancer cells. HIV, human immunodeficiency virus; CD4, cluster of differentiation 4;

are consumed together, the immune response may be improved and work synergistically, as appears in the case when Lactobacillus is given in combination with bifidobacteria. These consequences are delivered through activation of macrophages, increase in cytokines and activity of natural killer cells (Ouwehand et al. 2002; Perdigon et al. 1990). Both cellbased and antibody-based responses which are extremely complex immune system are involved in the potential transmittable agents. Certain diseases such as cancer, AIDS and leukaemia or ordinary conditions such as old age, pregnancy or stress may be outcome of immunodeficiency. Due to misdirected immune system activity, autoimmune diseases such as allergies and rheumatoid arthritis may occur. Children suffering with cystic fibrosis showed decreased severity of pneumonia when reacted with Lactobacillus rhamnosus GG (Parvez et al. 2006).

d'Ettorre et al. (2015) observed higher levels of immune response than healthy donors in combined antiretroviral therapy (cART)-treated patients. All patients showed a weak increase of $\mathrm{CD}^{+}$and $\mathrm{T}$ cells in the blood after 24 weeks of probiotic supplementation. The value of lipopolysaccharide
hsCRP, high-sensitivity C-reactive protein; B cells, t-lymphocyte cells; NK cells, natural killer cells; T cell, t-lymphocytes; IL-10, interleukin-10; IFN-g, interferon gamma. The pictures are taken from BioRender.com

binding protein (LBP) was normalized by probiotics while the levels of IL-6 and C-reactive protein (CRP) were similar. A significant reduction in hsCRP was observed after supplementation of probiotics. Thus, careful use of probiotics may improve the condition of patients suffering from HIV and other viral infections.

\section{Inflammatory bowel disease}

Ulcerative colitis (UC) and Crohn's disease (CD) are predominant and well defined forms of inflammatory bowel disease (IBD)(Ahlawat et al. 2021; Uhlig and Powrie 2018). UC is characterized by the inflammation located in the colon, which begins in the rectum and spreads proximally in a uniform pattern including periappendiceal region (Khor et al. 2011). Contrary to this, in $\mathrm{CD}$, any part of the GI tract is affected, most commonly non-continuous terminal ileal region. Unlike $\mathrm{UC}$, it is commonly associated with anatomical complications such as strictures, fistulas and abscesses (Khor et al. 2011).

Appraisal of the human genome by the collaborative research groups has successfully identified genetic loci and 


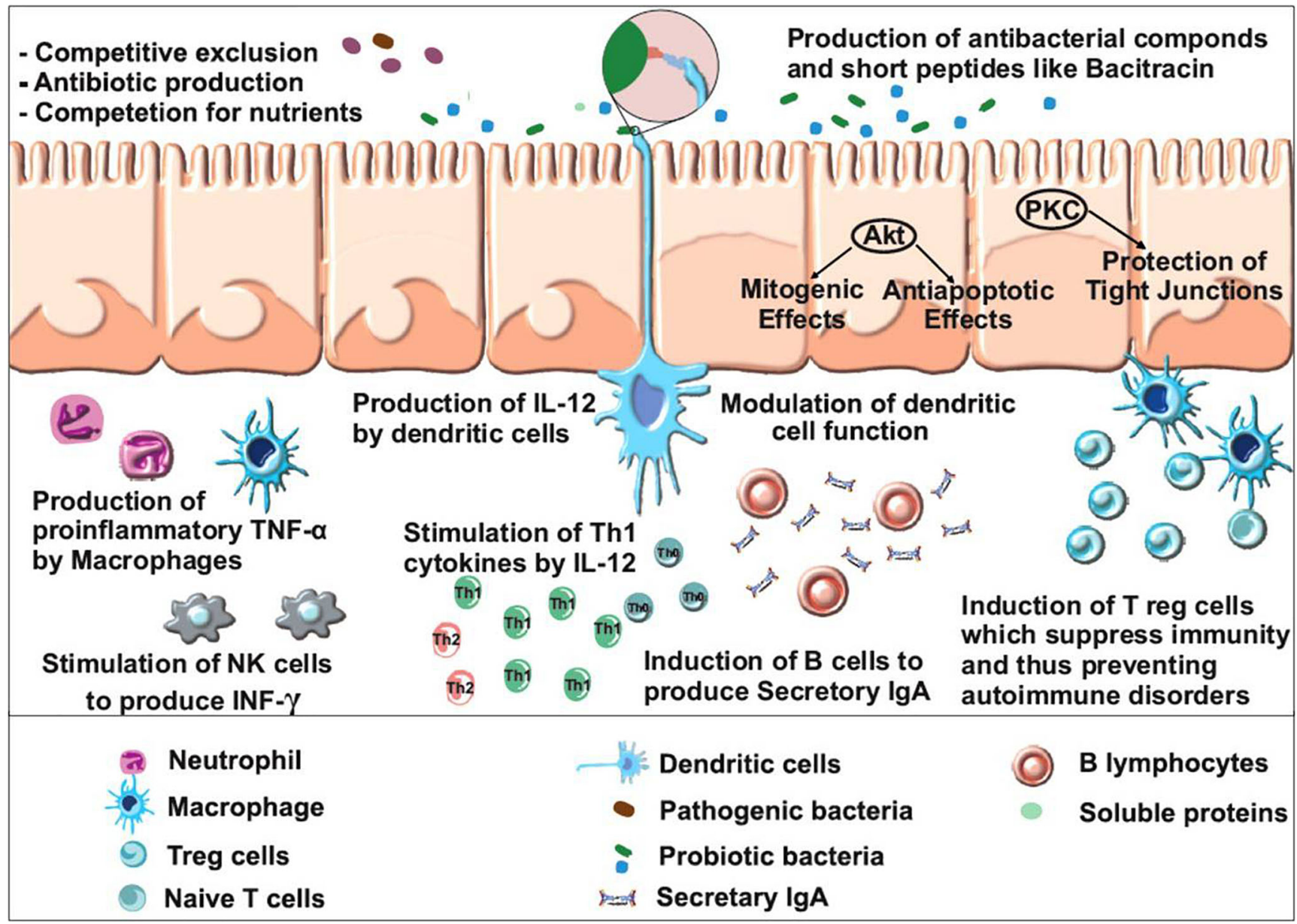

Fig. 2 A schematic diagram showing the modulation of host immune system by probiotics and their derivatives. Akt, protein kinase B; PKC, protein kinase C; TNF $\alpha$, tumour necrosis factor $\alpha$; NK cells, natural killer cells; IL-12, interleukin-12; Th1, type $1 \mathrm{t}$ helper; IgA, immunoglobulin A

genes responsible for IBD susceptibility (Anderson et al. 2011; Franke et al. 2010). Using genome-wide association studies (GWAS) and meta-analysis of loci, 230 disease loci linked to polygenic IBD have been identified and reported (de Lange et al. 2017; Jostins et al. 2012; Liu et al. 2015). Furthermore, the disease mechanism has been studied by the identification of candidate gene networks and genetic variants which affect host-microbe interactions, like microbe sensing within the NOD2 pathway. GWAS has resulted in the identification of the role of autophagy in the pathogenicity of IBD. It has also emphasized the key role of inflammatory signalling pathways (e.g. IL-23-driven T helper cell responses) (Uhlig and Muise 2017). Earlier, Anderson and co-workers reported 29 loci containing genes that suggested the role of epithelial barrier function, cytokine-dependent signalling and intracellular defense in UC. They also reviled genetic overlap with CD (Anderson et al. 2011). About 30\% of IBD-related genetic loci allocated between UC and CD, indicated that these diseases share common pathways (Khor et al. 2011). Furthermore, $50 \%$ of IBD susceptibility loci showed association with other inflammatory diseases and autoimmune disorders. The genome data suggested that understanding the function of these shared genes and pathways is important in disease biology (Uhlig and Muise 2017).

Earlier, reduction in the complication of IBD has been reported in association with consumption of different strains of lactobacilli (Schultz and Sartor 2000; Ouwehand et al. 2002; Parvez et al. 2006; Murakami et al. 2012). Probiotics may improve intestinal mobility and relieve constipation possibly by reducing the $\mathrm{pH}$. It has also been reported that patients may get benefited with probiotic combination therapies in IBD. In CD patients, Saccharomyces boulardii was found to expand reduction time and reduce decline rates (Parvez et al. 2006). Yoon et al. (2014) have investigated the efficacy of treatment with probiotic consortia (e.g. Bifidobacterium longum, Streptococcus thermophilus, B. lactis, B. bifidum, Lactobacillus acidophilus and L. rhamnosus) on the symptoms of IBS and also gut microbiota alterations (Yoon et al. 2014). Interestingly, multispecies probiotics were found to be effective in IBS cases, and it also affects the composition of intestinal microbiota (Yoon et al. 2014). 
Different species of Lactobacillus have been reported to stimulate mucosal cytokine profiles in the gut immune system (Perdigon et al. 1990). Mice fed with L. acidophilus, L. delbrueckii subsp. bulgaricus and L. casei showed significant induction in Th1 cytokines, IL-2 and IL-12. Furthermore, the probiotic cocktail stimulated secretion of IL-10 by dendritic cell and inhibited production of IFN-g(Hart et al. 2004). Earlier, probiotic effect on epithelial lining has been reported both in vitro and in vivo in suckling rats. Stabilization of the gut barrier in IBD case by probiotic intake is proposed to be a key factor for its therapeutic efficacy (Sheil et al. 2007).

Ulcerative colitis being chronic and inflammatory, in some cases, it results into necrosis, ulceration and perforation of the intestine (Fedorak and Madsen 2004). Young people between 20 and 40 years of age are mostly affected. The developed countries of North America and Europe are more familiar with this disease. A VSL\#3 preparation which consists of eight probiotics namely $L$. delrueckii subsp. bulgaricus, $L$. acidophilus, $L$. casei, L. plantarum, B. longum, B. breve, Streptococcus salivarius subsp. thermophilus and $B$. infantis significantly reduced the reoccurrence of symptoms in patients (Floch 2010).

Crohn's disease results in intestinal imbalance of microbiota and a reduction in microbial biodiversity (dysbiosis)(Manichanh et al. 2006; Marlicz et al. 2018; Ott et al. 2004). Till date, the exact causes of CD are unrevealed, though immunological response to disrupted gut microbiota is likely to be involved in genetically susceptible individuals (Ahlawat et al. 2021; Khor et al. 2011). The clinical management of Crohn's disease is very complex due to its heterogenous symptoms, occurrence and severity. Therefore, an early intervention of immunomodulators and/or probiotics to the critical patients will show more benefits (Cleynen et al. 2013). Currently, the disease is managed by a combination of immune-suppressant, diet management and surgery, if needed. Probiotics such as B. infantis, B. bifidum, L. acidophilus, L. plantarum, L. salivarius and Pediococcus pentosaceus have been shown to positively regulate immune functions or responses, which involve humoral, cellular or non-specific immunity. However, several probiotics have been tested in animal models with diverse and nonconclusive results. Contrary to this, increase in Bifidobacterium and Lactobacillus population (Wang et al. 2014) and decrease in Clostridium leptum and Faecalibacterium prausnitzii(Prosberg et al. 2016) have been reported in active CD patients (Ahlawat et al. 2021). Importantly, $F$. prausnitzii has been observed to be associated with an increased risk of recurrence of ileal CD after surgery (Sokol et al. 2008) and the decreased butyrate producers (e.g. Methanobrevibacter, Christensenellaceae and Oscillospira) in active CD (Pascal et al. 2017). Similar observations in CD patients were made for all butyrate producers, for example, Roseburia inulinivorans, Blautia faecis, Ruminococcus torques, Bacteroides uniformis and Clostridium lavalense(Marlicz et al. 2018; Takahashi et al. 2016).

\section{Anti-carcinogenic effects}

The carcinogens can be consumed or produced by metabolic activity of microbes that are present in GI system. Probiotics may decrease the exposure to carcinogens by detoxifying them, by producing metabolic products leading to apoptosis, by stimulating immune response and by changing the environmental conditions of the intestine to inhibit tumour cells (Donaldson 2004). Probiotics also inhibit the growth of bacteria converting pro-carcinogens into carcinogens. Lactobacillus rhamnosus GG reduces the tumour occurrence in experimental animals with colon cancer (Goldin et al. 1996). Using probiotics, consumers are benefited with the variety of important therapeutic and nutritional benefits including anti-mutagenic and anti-carcinogenic activity (Parvez et al. 2006).

The modern life style (adulterated food and several stresses) is associated with cancer related death all over the world which reduces lymphokine-activated killer (LAK) cells and natural killer (NK) cells. Earlier, lymphoid tumour cell has been reported to be suppressed by the NK cells in vitro without any immunization or sensitization (Strobel and Strid 2002). A low NK cell activity enhances the menace of developing cancer cells; moreover, NK cells are induced by cytokines (e.g. IFN- $\gamma$ and IL-12). Human with relatively low NK cell activity, supplemented with fermented milk containing L. casei strain Shirota and L. rhamnosus HN001, has been reported to increase NK cell activity useful in cancer prevention (Nagao et al. 2000; Sheih et al. 2001).

In elderly people, several health issues are linked to agerelated immune suppression (immunosenescence), which reduces the disease combat ability. They also have a predisposition towards Th2 phenotype expression due to reduced NK cell activity (Ongrádi and Kövesdi 2010). Gill et al. (2001) observed increase in peripheral blood cells labelled singly for CD56 (marker for NK cells) following consumption of L. rhamnosus HN019. Consumption of LAB-supplemented milk (e.g. L. rhamnosus HN001 and L. rhamnosus HN019) significantly increased peripheral blood mononuclear cells tumoricidal activity (Gill et al. 2001). Furthermore, reduction of NK activity is also associated with smoking, suggesting that risk of cancer can be reduced by the reduction in smoking (Morimoto et al. 2005). In a study, fermented milk with L. casei strain Shirota has shown improvement in the bladder cancer (Ohashi et al. 2002) and NK cell activity in male smokers. It has been suggested that immunomodulation by probiotic bacteria may enhance the host immune system to produce IL-12 (via stimulation of macrophages), which eventually stimulate helper $\mathrm{T}$ cells. The stimulated helper $\mathrm{T}$ cells 
produced IFN- $\gamma$ providing immunity against tumour cells (Taverniti and Guglielmetti 2011).

Colorectal cancer is the most common forms of cancer in developed countries (Kolida and Gibson 2011). The change in microflora composition and increase in their enzymes like azoreductase, $\beta$-glucuronidase, nitroreductase, glycocholic acid reductase and urease have been linked with colon cancer. Probiotics have been reported to inhibit cancer development in the colon by lowering these microbial enzymes and by degrading nitroso-compounds(Mombelli and Gismondo 2000). These enzymes transform cancer-causing molecules into carcinogens and thus increase the risk of colorectal cancer (Fuller 1989).

There are appreciable literature on the mucosal colonization and metabolic activity of the intestinal microflora in relation to the age related aetiology of colon cancer (Biragyn and Ferrucci 2018). Ageing is associated with reduced microbiota useful in maintaining healthy gut. Development of gut dysbiosis and passage of microbial products through mucus membrane contributes to the chronic inflammation, which negatively control the immune system and impairs the removal of damaged and older cells, thus enabling tumour outgrowth (Biragyn and Ferrucci 2018). Supplementation of the diet with bile-resistant $L$. acidophilus of human origin showed a significant decline in the key microbial enzymes responsible for the induction of colon cancer (Sharma and Shukla 2016). Kim et al. (2006) found Lactobacillus rhamnosus ATCC9595 useful in preventing colon cancer in human cancer cell lines due to the induction of apoptosis by exopolysaccharides. Different strains of Bifidobacterium, L. acidophilus, L. helveticus or a mixture of $L$. bulgaricus and Streptococcus thermophilus have been reported to show inhibition in the proliferation of the cancerous cells (Baricault et al. 1995). In brief, probiotics reduce tumour cell viability (Papadimitriou et al. 2015) and suppress colorectal carcinomas (McIntyre et al. 2015; Reddy and Rivenson 1993).

\section{Conclusions and future perspectives}

Probiotic bacteria positively affect the human health by stimulating immune system and inhibition of pathogens. Due to their multifarious health benefits, there has been a significant interest in probiotics and prebiotics in healthcare and consumer products. However, an extensive study data is limited to a few probiotics and prebiotics. Various clinical studies have supported the role of probiotics and prebiotics alone and in combination (synbiotics) with each other in the treatment and prevention a large number of life-threatening diseases including cancer, HIV infection, gut diseases and many more. There are sufficient evidences that probiotics and their derivatives may also pay significant role in the management of COVID19. Therefore, an utmost need of an hour is to clinically validate some more probiotics and prebiotics along with synbiotics for human health and therapeutic applications. Modern techniques based on molecular biology, genetic engineering, system biology, multiomics, nanotechnology and immunology must be utilized for thorough understanding of structure and function of microbiome with respect to probiotics and prebiotics. These studies will help in understanding the interaction among human body functions and microbiome. Therefore, scientists from different fields (academic institutions, clinicians and industries) should come together and join hands in this direction through a collaborative translational research attempting to directly relate insights from the lab to the manufacturers, the consumers and the clinicians.

Author contribution SKT, BJ and KK conceived and designed the manuscript. MKY and IK designed, wrote and formatted the manuscript. All authors read and approved the manuscript.

Funding This work was supported by the Department of Biotechnology under grant (BT/PR8911/NDB/39/423/2013 and BT/PR8306/PID/6/738/ 2013), Indian Council of Medical Research under grant (5/9/1117/2013NUT), Council of Scientific and Industrial Research under grant (38(1220)/09/EMR-II), Department of Science and Technology under grant (SR/FT/LS-177/2008), Indian National Science Academy under grant (IA/INDO-AUST/F-4/2017/1872), University Grant Commission under grant (36-38/2008/SR) and Indo-US Science and Technology Forum under grant (Fellowships/2010/15).

Data availability No data is associated with the manuscript.

Code availability Not applicable.

\section{Declarations}

Ethics approval Not applicable.

Consent to participate Not applicable.

Consent for publication Not applicable.

Competing interests The authors declare no competing interests.

\section{References}

Aachary AA, Prapulla SG (2011) Xylooligosaccharides (XOS) as an emerging prebiotic: microbial synthesis, utilization, structural characterization, bioactive properties, and applications. Compr Rev Food Sci Food Saf 10:2-16. https://doi.org/10.1111/j.1541-4337. 2010.00135.x

Acuna L, Morero DR, Bellomio B (2011) Development of widespectrum hybrid bacteriocins for food biopreservation. Food Bioprocess Technol 4:1029-1049. https://doi.org/10.1007/s11947010-0465-7

Ahlawat S, Asha, Sharma KK (2020a) Immunological co-ordination between gut and lungs in SARS-CoV-2 infection. Virus Res 286: 198103. https://doi.org/10.1016/j.virusres.2020.198103 
Ahlawat S, Asha, Sharma KK (2021)Gut-organ axis: a microbial outreach and networking. Lett Appl Microbiol 72:636-668. https:// doi.org/10.1111/lam.13333

Ahlawat S, Singh D, Yadav A, Singh AK, Virdi JS, Sharma KK (2020b) Proteomic analysis reveals the damaging role of low redox laccase from Yersinia enterocolitica strain 8081 in the midgut of Helicoverpa armigera. Biotechnol Lett 42:2189-2210. https://doi. org/10.1007/s10529-020-02925-x

Ammor S, Tauveron G, Dufour E, Chevallier I (2006) Antibacterial activity of lactic acid bacteria against spoilage and pathogenic bacteria isolated from the same meat small-scale facility: 1-Screening and characterization of the antibacterial compounds. Food Control 17: 454-461. https://doi.org/10.1016/j.foodcont.2005.02.006

Anderson CA, Boucher G, Lees CW, Franke A, D'Amato M, Taylor KD, Lee JC, Goyette P, Imielinski M, Latiano A, Lagacé C (2011)Metaanalysis identifies 29 additional ulcerative colitis risk loci, increasing the number of confirmed associations to 47. Nat Genet 43:246252. https://doi.org/10.1038/ng.764

Anukam KC, Osazuwa EO, Osadolor HB, Bruce AW, Reid G (2008) Yogurt containing probiotic Lactobacillus rhamnosusGR-1 and L. reuteri $\mathrm{RC}-14$ helps resolve moderate diarrhea and increases CD4 count in HIV/AIDS patients. J Clin Gastroenterol 42:239 243. https://doi.org/10.1097/MCG.0b013e31802c7465

Arnold C (2013) The new danger of synthetic drugs. Lancet 382:15-16. https://doi.org/10.1016/S0140-6736(13)61512-3

Barcenilla C, Ducic M, López M, Prieto M, Álvarez-Ordóñez A (2021) Application of lactic acid bacteria for the biopreservation of meat products: a systematic review. Meat Sci 183:108661. https://doi.org/ 10.1016/j.meatsci.2021.108661

Barefoot SF, Klaenhammer TR (1983) Detection and activity of lactacin B, a bacteriocin produced by Lactobacillus acidophilus. Appl Environ Microbiol 45:1808-1815. https://doi.org/10.1128/aem.45. 6.1808-1815.1983

Baricault L, Denariaz G, Houri JJ, Bouley C, Sapin C, Trugnan G (1995) Use of HT-29, a cultured human colon cancer cell line, to study the effect of fermented milks on colon cancer cell growth and differentiation. Carcinogenesis 16:245-252. https://doi.org/10.1093/carcin/ 16.2.245

Belkaid Y, Hand TW (2014) Role of the microbiota in immunity and inflammation. Cell 157:121-141. https://doi.org/10.1016/j.cell. 2014.03.011

Berada N, Lemeland J, Laroche G, Thouveno P, Piaia M (1991)Bifidobacterium from fermented milks: survival during gastric transit. J Dairy Sci 74:409-413. https://doi.org/10.3168/jds. S0022-0302(91)78183-6

Bernardini S, Tiezzi A, Laghezza Masci V, Ovidi E (2018) Natural products for human health: an historical overview of the drug discovery approaches. Nat Prod Res 32:1926-1950. https://doi.org/10.1080/ 14786419.2017.1356838

Bhattacharya R, Gupta AM, Mitra S, Mandal S, Biswas SR (2021) A natural food preservative peptide nisin can interact with the SARSCoV-2 spike protein receptor human ACE2. Virol 552:107-111. https://doi.org/10.1016/j.virol.2020.10.002

Biedrzycka E, Bielecka M (2004) Prebiotic effectiveness of fructans of different degrees of polymerization. Trends Food Sci Technol 15: 170-175. https://doi.org/10.1016/j.tifs.2003.09.014

Bielecka M, Biedrzycka E, Majkowska A (2002) Selection of probiotics and prebiotics for synbiotics and confirmation of their in vivo effectiveness. Food Res Int 35:125-131. https://doi.org/10.1016/S09639969(01)00173-9

Biragyn A, Ferrucci L (2018) Gut dysbiosis: a potential link between increased cancer risk in ageing and inflammaging. Lancet Oncol 19:e295-e304. https://doi.org/10.1016/S1470-2045(18)30095-0

Bottcher MF, Nordin EK, Sandin A, Midtvedt T, Björkstén B (2000) Microflora associated characteristics in faeces from allergic and nonallergic infants. Clin Exp Allergy 30:1591-1596. https://oi. org/10.1046/j.1365-2222.2000.00982.x

Brandtzaeg P (2010) Function of mucosa-associated lymphoid tissue in antibody formation. Immunol Invest 39:303-355. https://doi.org/10. 3109/08820131003680369

Bruno FA, Lankaputhra WEV, Shah NP (2002) Growth, viability and activity of Bifidobacterium spp. in skim milk containing prebiotics. J Food Sci 67:2740-2744. https://doi.org/10.1111/j.1365-2621.2002. tb08807.x

Buck LM, Gilliland SE (1994) Comparisons of freshly isolated strains of Lactobacillus acidophilus of human intestinal origin for ability to assimilate cholesterol during growth. J Dairy Sci 77:2925-2933. https://doi.org/10.3168/jds.S0022-0302(94)77233-7

Chang YL, Rossetti M, Vlamakis H, Casero D, Sunga G, Harre N, Miller S, Humphries R, Stappenbeck T, Simpson KW, Sartor RB (2019) A screen of Crohn's disease-associated microbial metabolites identifies ascorbate as a novel metabolic inhibitor of activated human T cells. Mucosal Immunol 12:457-467. https://doi.org/10.1038/ s41385-018-0022-7

Chen X, Liu Y, Jin J, Liu H, Hao Y, Zhang H, Xie Y (2021) YbfA regulates the sensitivity of Escherichia coli K12 to Plantaricin $\mathrm{BM}-1$ via the BasS/BasRtwo-component regulatory system. Front Microbiol 12:659198. https://doi.org/10.3389/fmicb.2021.659198

Christensen HR, Frøkiær H, Pestka JJ (2002) Lactobacilli differentially modulate expression of cytokines and maturation surface markers in murine dendritic cells. J Immunol 168:171-178. https://doi.org/10. 4049/jimmunol.168.1.171

Cicero AF, Fogacci F, Bove M, Giovannini M, Borghi C (2021) Impact of a short-term synbiotic supplementation on metabolic syndrome and systemic inflammation in elderly patients: a randomized placebo-controlled clinical trial. Eur J Nutr 60:655-663. https:// doi.org/10.1007/s00394-020-02271-8

Ciprandi G, Cirillo I, Vizzaccaro A, Milanese M, Tosca MA (2004) Nasal obstruction in patients with seasonal allergic rhinitis: relationships between allergic inflammation and nasal airflow. Int Arch Allergy Immunol 134:34 40. https://doi.org/10.1159/000077531

Cleynen I, González JR, Figueroa C, Franke A, McGovern D, Bortlík M, Crusius BJ, Vecchi M, Artieda M, Szczypiorska M, Bethge J (2013) Genetic factors conferring an increased susceptibility to develop Crohn's disease also influence disease phenotype: results from the IBDchip European Project. Gut 62:1556-1565. https://doi.org/10. 1136/gutjnl-2012-304151

Coussement P (1996)Pre-and synbiotics with inulin and oligofructose: promising developments in functional foods. Food Technol Eur 2: $102-104$

Cummings JH, Macfarlane GT, Englyst HN (2001) Prebiotic digestion and fermentation. Am J Clin Nutr 73:415s-420s. https://doi.org/10. $1093 / \mathrm{ajcn} / 73.2 .415 \mathrm{~s}$

Dai C, Zhao DH, Jiang M (2012) VSL\#3 probiotics regulate the intestinal epithelial barrier in vivo and in vitro via the $\mathrm{p} 38$ and ERK signaling pathways. Int J Mol Med 29:202-208. https://doi.org/10.3892/ ijmm.2011.839

Dai M, Li Y, Xu L, Wu D, Zhou Q, Li P, Gu Q (2021) A novel bacteriocin from Lactobacillus pentosus ZFM94 and its antibacterial mode of action. Front Nutr 8:710862. https://doi.org/10.3389/fnut.2021. 710862

Davani-Davari D, Negahdaripour M, Karimzadeh I, Seifan M, Mohkam M, Masoumi SJ, Berenjian A, Ghasemi Y (2019) Prebiotics: definition, types, sources, mechanisms, and clinical applications. Foods 8 : 92. https://doi.org/10.3390/foods 8030092

De Biasi S, Meschiari M, Gibellini L, Bellinazzi C, Borella R, Fidanza L, Gozzi L, Lannone A, Lo Tartaro D, Mattioli M, Paolini A, Menozzi M, Milić J, Franceschi G, Fantini R, Tonelli R, Sita M, Sarti M, Trenti T, Brugioni L, Cicchetti L, Facchinetti F, Pietrangelo A, Clini E, Girardis M, Guaraldi G, Mussini C, Cossarizza A (2020) Marked $\mathrm{T}$ cell activation, senescence, exhaustion and skewing towards 
TH17 in patients with COVID-19 pneumonia. Nat Commun 11: 3434. https://doi.org/10.1038/s41467-020-17292-4

de Lange KM, Moutsianas L, Lee JC, Lamb CA, Luo Y, Kennedy NA, Jostins L, Rice DL, Gutierrez-Achury J, Ji SG, Heap G, Nimmo ER, Edwards C, Henderson P, Mowat C, Sanderson J, Satsangi J, Simmons A, Wilson DC, Tremelling M, Hart A, Mathew CG, Newman WG, Parkes M, Lees CW, Uhlig H, Hawkey C, Prescott NJ, Ahmad T, Mansfield JC, Anderson CA, Barrett JC (2017)Genome-wide association study implicates immune activation of multiple integrin genes in inflammatory bowel disease. Nat Genet 49:256-261. https://doi.org/10.1038/ng.3760

Desai AR (2008) Strain identification, viability and probiotics properties of Lactobacillus casei. Ph.D. Thesis, School of Biomedical and Health Sciences. Victoria University, Werribee Campus Victoria, Australia

d'Ettorre G, Ceccarelli G, Giustini N, Serafino S, Calantone N, De Girolamo G, Bianchi L, Bellelli V, Ascoli-Bartoli T, Marcellini S, Turriziani O, Brenchley JM, Vullo V (2015) Probiotics reduce inflammation in antiretroviral treated, HIV-infected individuals: results of the "probio-HIV" clinical trial. PLoS ONE 10:e137200. https://doi.org/10.1371/journal.pone. 0137200

Donaldson MS (2004) Nutrition and cancer: a review of the evidence for an anti-cancer diet. Nutr J 3:1-21. https://doi.org/10.1186/14752891-3-19

Eslamparast T, Zamani F, Hekmatdoost A, Sharafkhah M, Eghtesad S, Malekzadeh R, Poustchi H (2014) Effects of synbiotic supplementation on insulin resistance in subjects with the metabolic syndrome: a randomised, double-blind, placebo-controlled pilot study. Br J Nutr 112:438-445. https://doi.org/10.1017/S0007114514000919

Fathizadeh H, Pakdel F, Saffari M, Esmaeili DD, Momen-Heravi M, Dao S, Ganbarov K, Kafil HS (2021) Bacteriocins: recent advances in application as an antimicrobial alternative. Curr Pharm Biotechnol. https://doi.org/10.2174/1389201022666210907121254

Fedorak RN, Madsen KL (2004) Probiotics and the management of inflammatory bowel disease. Inflamm Bowel Dis 10:286-299. https:// doi.org/10.1097/00054725-200405000-00018

Floch MH (2010) Probiotic therapy for ulcerative colitis. J Clin Gastroenterol 44:237-238. https://doi.org/10.1097/MCG. 0b013e3181 cf837f

Franke A, McGovern DP, Barrett JC, Wang K, Radford-Smith GL, Ahmad T, Lees CW, Balschun T, Lee J, Roberts R, Anderson CA (2010)Genome-wide meta-analysis increases to 71 the number of confirmed Crohn's disease susceptibility loci. Nat Genet 42:11181125. https://doi.org/10.1038/ng.717

Fuller R (1989) Probiotics in man and animals. J Appl Bacteriol 66:365-378

Gibson GR, Beatty ER, Wang XIN, Cummings JH (1995) Selective stimulation of bifidobacteria in the human colon by oligofructose and inulin. Gastroenterol 108:975-982. https://doi.org/10.1016/ 0016-5085(95)90192-2

Gibson GR, Hutkins R, Sanders ME, Prescott SL, Reimer RA, Salminen SJ, Scott K, Stanton C, Swanson KS, Cani PD, Verbeke K (2017) Expert consensus document: the International Scientific Association for Probiotics and Prebiotics (ISAPP) consensus statement on the definition and scope of prebiotics. Nat Rev Gastroenterol Hepatol 14:491-502. https://doi.org/10.1038/nrgastro.2017.75

Gibson GR, Roberfroid MB (1995) Dietary modulation of the human colonic microbiota: introducing the concept of prebiotics. J Nutr 125:1401-1412. https://doi.org/10.1093/jn/125.6.1401

Gill HS (1998) Stimulation of the immune system by lactic cultures. Int Dairy J 8:535-544. https://doi.org/10.1016/S0958-6946(98) 00074-0

Gill HS, Rutherfurd KJ, Cross ML (2001) Dietary probiotic supplementation enhances natural killer cell activity in the elderly: an investigation of age-related immunological changes. J Clin Immunol 21: 264-271. https://doi.org/10.1023/A:1010979225018
Gilliland SE, Speck ML (1977) Deconjugation of bile acids by intestinal lactobacilli. Appl Environ Microbiol 33:15-18. https://doi.org/10. 1128/aem.33.1.15-18.1977

Gogineni VK, Morrow LE, Gregory PJ, Malesker MA (2013) Probiotics: history and evolution. J Anc Dis Prev Rem 1:1-7. https://doi.org/10. 4172/2329-8731.1000107

Goldin BR, Gualtieri LJ, Moore RP (1996) The effect of Lactobacillus GG on the initiation and promotion of DMH-induced intestinal tumors in the rat. Nutr Cancer 25:197-204. https://doi.org/10.1080/ 01635589609514442

Gori A, Rizzardini G, Van't Land B, Amor KB, van Schaik J, Torti C, Quirino T, Tincati C, Bandera A, Knol J, Benlhassan-Chahour K, Trabattoni D, Bray D, Vriesema A, Welling G, Garssen J, Clerici M (2011) Specific prebiotics modulate gut microbiota and immune activation in HAART-naive HIV-infected adults: results of the "COPA" pilot randomized trial. Mucosal Immunol 4:554-563. https://doi.org/10.1038/mi.2011.15

Guarino MPL, Altomare A, Emerenziani S, Di Rosa C, Ribolsi M, Balestrieri P, Iovino P, Rocchi G, Cicala M (2020) Mechanisms of action of prebiotics and their effects on gastro-intestinal disorders in adults. Nutrients 12:1037. https://doi.org/10.3390/nu12041037

Gullon P, Moura P, Esteves MP, Girio FM, Domínguez H, Parajó JC (2008) Assessment on the fermentability of xylooligosaccharides from rice husks by probiotic bacteria. J Agric Food Chem 56: 7482-7487. https://doi.org/10.1021/jf800715b

Harrison VC, Peat G, de Heese HV (1974) Fetal growth in relation to histamine concentration in urine. J Obstet Gynaecol Br Commonw 81:686-690. https://doi.org/10.1111/j.1471-0528.1974.tb00541.x

Hart AL, Lammers K, Brigidi P, Vitali B, Rizzello F, Gionchetti P, Campieri M, Kamm MA, Knight SC, Stagg AJ (2004) Modulation of human dendritic cell phenotype and function by probiotic bacteria. Gut 53:1602-1609. https://doi.org/10.1136/gut.2003.037325

Hartemink R, Rombouts FM (1997) Gas formation from oligosaccharides by the intestinal microflora. In: Boehm G (ed) International Symposium on Pre and Probiotics. Wageningen Graduate School, Wageningen, pp 57-66

Hilton E, Kolakowski P, Singer C, Smith M (1997) Efficacy of Lactobacillus GG as a diarrheal preventive in travelers. J Travel Med 4:41-43. https://doi.org/10.1111/j.1708-8305.1997.tb00772.x

Hoffmann M, Kleine-Weber H, Schroeder S, Krüger N, Herrler T, Erichsen S, Schiergens TS, Herrler G, Wu NH, Nitsche A, Müller MA (2020)SARS-CoV-2 cell entry depends on ACE2 and TMPRSS2 and is blocked by a clinically proven protease inhibitor. Cell 181:271-280. https://doi.org/10.1016/j.cell.2020.02.052

Hughes DB, Hoover DG (1995) Viability and enzymatic activity of bifidobacteria in milk. J Dairy Sci 78:268-276. https://doi.org/10. 3168/jds.S0022-0302(95)76634-6

Hummelen R, Changalucha J, Butamanya NL, Koyama TE, Cook A, Habbema JD, Reid G (2011) Effect of 25 weeks probiotic supplementation on immune function of HIV patients. Gut Microbes 2:80 85. https://doi.org/10.4161/gmic.2.2.15787

Ipar N, Aydogdu SD, Yildirim GK, Inal M, Gies I, Vandenplas Y, Dinleyici EC (2015) Effects of synbiotic on anthropometry, lipid profile and oxidative stress in obese children. Benef Microbes 6: 775-782. https://doi.org/10.3920/BM2015.0011

Irvine SL, Hummelen R, Hekmat S (2011) Probiotic yogurt consumption may improve gastrointestinal symptoms, productivity, and nutritional intake of people living with human immunodeficiency virus in Mwanza, Tanzania. Nutr Res 31:875-881. https://doi.org/10.1016/j. nutres.2011.10.005

Isolauri E, Sütas Y, Kankaanpää P, Arvilommi H, Salminen S (2001) Probiotics: effects on immunity. Am J Clin Nutr 73:444s-450s. https://doi.org/10.1093/ajcn/73.2.444s

Jostins L, Ripke S, Weersma RK, Duerr RH, McGovern DP, Hui KY, Lee JC, Schumm LP, Sharma Y, Anderson CA, Essers J (2012)Host-microbe interactions have shaped the genetic 
architecture of inflammatory bowel disease. Nature 491:119-124. https://doi.org/10.1038/nature11582

Kadowaki N (2007) Dendritic cells: a conductor of T cell differentiation. Allergol Int 56:193-199. https://doi.org/10.2332/ allergolint.R-07-146

Kaila M, Isolauri E, Soppi E, Virtanen E, Laine S, Arvilommi H (1992) Enhancement of the circulating antibody secreting cell response in human diarrhea by a human Lactobacillus strain. Pediatr Res 32: 141-144. https://doi.org/10.1203/00006450-199208000-00002

Kanauchi O, Andoh A, AbuBakar S, Yamamoto N (2018) Probiotics and paraprobiotics in viral infection: clinical application and effects on the innate and acquired immune systems. Curr Pharm Des 24:710 717. https://doi.org/10.2174/1381612824666180116163411

Kawashima T, Hayashi K, Kosaka A, Kawashima M, Igarashi T, Tsutsui H, Tsuji NM, Nishimura I, Hayashi T, Obata A (2011)Lactobacillus plantarum strain YU from fermented foods activates Th1 and protective immune responses. Int Immunopharmacol 11:2017-2024. https://doi.org/10.1016/j.intimp.2011.08.013

Khanna S, Bishnoi M, Kondepudi KK, Shukla G (2020) Isolation, characterization and anti-inflammatory mechanism of probiotics in lipopolysaccharide-stimulated RAW 264.7 macrophages. World J Microbiol Biotechnol 36:74. https://doi.org/10.1007/s11274-02002852-Z

Khor B, Gardet A, Xavier RJ (2011) Genetics and pathogenesis of inflammatory bowel disease. Nature 474:307-317. https://doi.org/10. 1038/nature10209

Kidd P (2003)Th1/Th2 balance: the hypothesis, its limitations, and implications for health and disease. Altern Med Rev 8:223-246

Kilara A, Shahani KM (1976) Lactase activity of cultured and acidified dairy products. J Dairy Sci 59:2031-2035. https://doi.org/10.3168/ jds.S0022-0302(76)84484-0

Kim JU, Kim YH, Han KS, Oh SJ, Whang KY, Kim JN, Kim SH (2006) Function of cell-bound and released exopolysaccharides produced by Lactobacillus rhamnosus ATCC 9595. J Microbiol Biotechnol 16:939-945

Kohmoto T, Fukui F, Takaku H, Machida Y, Arai M, Mitsuoka T (1988) Effect of isomalto-oligosaccharides on human fecal flora. Bifidobacteria Microflora 7:61-69. https://doi.org/10.12938/ bifidus1982.7.2 61

Kolida S, Gibson GR (2011) Synbiotics in health and disease. Ann Rev Food Sci Technol 2:373-393. https://doi.org/10.1146/annurevfood-022510-133739

Korhonen J (2010) Antibiotic resistance of lactic acid bacteria. Dissertations, in Forestry and Natural Sciences, University of Eastern Finland

Lambert J, Hull R (1996) Upper gastrointestinal tract disease and probiotics. Asia Pac J Clin Nutr 5:31-35

Lankaputhra WEV, Shah NP, Britz ML (1996) Evaluation of media for selected enumeration of Lactobacillus acidophilus and Bifidobacterium spp. Food Australia 48:113-118

Laroia S, Martin J (1990) Bifidobacteria as possible dietary adjuncts in cultured dairy products-a review. Cult Dairy Prod J 25:18-22

Lee YK, Nomoto K, Salminen S, Gorbach SL (1999) Handbook of probiotics. John Wiley \& Sons, New York

Levy J (2000) The effects of antibiotic use on gastrointestinal function. Am J Gastroenterol 95:S8-S10. https://doi.org/10.1016/s00029270(99)00808-4

Lidbeck A, Allinger UG, Orrhage KM, Ottova L, Brismar B, Gustafsson J, Rafter JJ, Nord CE (1991) Impact of Lactobacillus acidophilus supplements on the faecal microflora and soluble faecal bile acids in colon cancer patients. Microbial Ecol Health Dis 4:81-88. https:// doi.org/10.3109/08910609109140267

Linares DM, Gomez C, Renes E, Fresno JM, Tornadijo ME, Ross RP, Stanton C (2017) Lactic acid bacteria and bifidobacteria with potential to design natural biofunctional health-promoting dairy foods. Front Microbiol 8:846. https://doi.org/10.3389/fmicb.2017.00846
Liu G, Wang H, Griffiths WM, Li P (2011) Heterologous extracellular production of enterocin $\mathrm{P}$ in Lactococcus lactis by a food-grade expression system. Eur Food Res Technol 233:123-129. https:// doi.org/10.1007/s00217-011-1494-9

Liu JZ, van Sommeren S, Huang H, Ng SC, Alberts R, Takahashi A, Ripke S, Lee JC, Jostins L, Shah T, Abedian S, Cheon JH, Cho J, Dayani NE, Franke L, Fuyuno Y, Hart A, Juyal RC, Juyal G, Kim WH, Morris AP, Poustchi H, Newman WG, Midha V, Orchard TR, Vahedi H, Sood A, Sung JY, Malekzadeh R, Westra HJ, Yamazaki $\mathrm{K}$, Yang SK, International Multiple Sclerosis Genetics Consortium, International IBD Genetics Consortium, Barrett JC, Alizadeh BZ, Parkes M, Bk T, Daly MJ, Kubo M, Anderson CA, Weersma RK (2015) Association analyses identify 38 susceptibility loci for inflammatory bowel disease and highlight shared genetic risk across populations. Nat Genet 47:979-986. https://doi.org/10.1038/ng. 3359

Louis P, Flint HJ, Michel C (2016) How to manipulate the microbiota: Prebiotics. Adv Exp Med Biol 902:119-142. https://doi.org/10. 1007/978-3-319-31248-4 9

Mackowiak PA (2013) Recycling Metchnikoff: probiotics, the intestinal microbiome and the quest for long life. Front Public Health 1:52. https://doi.org/10.3389/fpubh.2013.00052

Majamaa H, Isolauri E (1997) Probiotics: a novel approach in the management of food allergy. J Allergy Clin Immunol 99:79-185. https:// doi.org/10.1016/S0091-6749(97)70093-9

Manichanh C, Rigottier-Gois L, Bonnaud E, Gloux K, Pelletier E, Frangeul L, Nalin R, Jarrin C, Chardon P, Marteau P, Roca J (2006) Reduced diversity of faecal microbiota in Crohn's disease revealed by a metagenomic approach. Gut 55:205-211. https://doi. org/10.1136/gut.2005.073817

Mann GV, Spoerig A (1974) Studies of a surfactant and cholesterolemia in the Masai. Am J Clin Nutr 27:464 469. https://doi.org/10.1093/ ajcn/27.5.464

Mantis NJ, Rol N, Corthésy B (2011) Secretory IgA's complex roles in immunity and mucosal homeostasis in the gut. Mucosal Immunol 4: 603-611. https://doi.org/10.1038/mi.2011.41

Markowiak P, Slizewska K (2017) Effects of probiotics, prebiotics, and synbiotics on human health. Nutrients 9:1021. https://doi.org/10. 3390/nu9091021

Marlicz W, Skonieczna-Żydecka K, Dabos KJ, Łoniewski I, Koulaouzidis A (2018) Emerging concepts in non-invasive monitoring of Crohn's disease. Therap Adv Gastroenterol 18:11. https:// doi.org/10.1177/1756284818769076

Martinez-Villaluenga C, Gomez R (2007) Characterization of bifidobacteria as starters in fermented milk containing raffinose family of oligosaccharides from lupin as prebiotic. Int Dairy J 17:116122. https://doi.org/10.1016/j.idairyj.2006.02.003

Masood MI, Qadir MI, Shirazi JH, Khan IU (2011) Beneficial effects of lactic acid bacteria on human beings. Crit Rev Microbiol 37:91-98. https://doi.org/10.3109/1040841X.2010.536522

McIntosh GH (1996) Probiotics and colon cancer prevention. Asia Pac J Clin Nutr 5:48-52

McIntyre RE, Buczacki SJ, Arends MJ, Adams DJ (2015) Mouse models of colorectal cancer as preclinical models. BioEssays 37:909-920. https://doi.org/10.1002/bies.201500032

Meng J, Xiao G, Zhang J, He X, Ou M, Bi J, Yang R, Di W, Wang Z, Li Z, Gao H (2020)Renin-angiotensin system inhibitors improve the clinical outcomes of COVID-19 patients with hypertension. Emerg Microbes Infect 9:757-760. https://doi.org/10.1080/22221751. 2020.1746200

Merson MH, Morris GK, Sack DA, Wells JG, Feeley JC, Sack RB, Creech WB, Kapikian AZ, Gangarosa EJ (1976) Travelers' diarrhea in Mexico. A prospective study of physicians and family members attending a congress. N Engl J Med 294:1299-1305. https://doi.org/ 10.1056/NEJM197606102942401 
Mishra C, Lambert J (1996) Production of anti-microbial substances by probiotics. Asia Pac J Clin Nutr 5:20-24

Mohamadzadeh M, Olson S, Kalina WV, Ruthel G, Demmin GL, Warfield KL, Bavari S, Klaenhammer TR (2005)Lactobacilli activate human dendritic cells that skew $\mathrm{T}$ cells toward $\mathrm{T}$ helper 1 polarization. Proc Natl Acad Sci U S A 102:2880-2885. https:// doi.org/10.1073/pnas.0500098102

Mombelli B, Gismondo MR (2000) The use of probiotics in medical practice. Int J Antimicrob Agents 16:531-536. https://doi.org/10. 1016/s0924-8579(00)00322-8

Monachese M, Cunningham-Rundles S, Diaz MA, Guerrant R, Hummelen R, Kemperman R, Kerac M, Kort R, Merenstein D, Panigrahi P, Ramakrishna B, Safdar N, Shane A, Trois L, Reid G (2011) Probiotics and prebiotics to combat enteric infections and HIV in the developing world: a consensus report. Gut Microbes 2: 198-207. https://doi.org/10.4161/gmic.2.3.16106

Morimoto K, Takeshita T, Nanno M, Tokudome S, Nakayama K (2005) Modulation of natural killer cell activity by supplementation of fermented milk containing Lactobacillus casei in habitual smokers. Prev Med 40:589-594. https://doi.org/10.1016/ j.ypmed.2004.07.019

Morotomi M (1996) Properties of Lactobacillus casei Shirota strain as probiotics. Asia Pac J Clin Nutr 5:29-30

Murakami K, Habukawa C, Nobuta Y, Moriguchi N, Takemura T (2012) The effect of Lactobacillus brevis KB290 against irritable bowel syndrome: a placebo-controlled double-blind crossover trial. Biopsychosoc Med 6:1-8. https://doi.org/10. 1186/1751-0759-6-16

Nagao F, Nakayama M, Muto T, Okumura K (2000) Effects of a fermented milk drink containing Lactobacillus casei strain Shirota on the immune system in healthy human subjects. Biosci Biotechnol Biochem 64:2706-2708. https://doi.org/10.1271/bbb.64.2706

Ohashi Y, Nakai S, Tsukamoto T, Masumori N, Akaza H, Miyanaga N, Kitamura T, Kawabe K, Kotake T, Kuroda M, Naito S (2002) Habitual intake of lactic acid bacteria and risk reduction of bladder cancer. Urol Int 68:273-280. https://doi.org/10.1159/000058450

Okazaki M, Fujikawa S, Mastumoto N (1990) Effects of xylooligosaccharides on growth of Bifidobacteria. Bifidobactetria Microflora 9:77-86. https://doi.org/10.12938/bifidus1982.9.2 77

Oksanen PJ, Salminen S, Saxelin M, Hämäläinen P, Ihantola-Vormisto A, Muurasniemi-Isoviita L, Nikkari S, Oksanen T, Pörsti I, Salminen E (1990) Prevention of travellers' diarrhoea by Lactobacillus GG. Ann Med 22:53-56. https://doi.org/10.3109/ 07853899009147242

Olaimat AN, Aolymat I, Al-Holy M, Ayyash M, Ghoush MA, AlNabulsi AA, Osaili T, Apostolopoulos V, Liu SQ, Shah NP (2020) The potential application of probiotics and prebiotics for the prevention and treatment of COVID-19. NPJ Sci Food 4:1-7. https://doi.org/10.1038/s41538-020-00078-9

Ongrádi J, Kövesdi V (2010) Factors that may impact on immunosenescence: an appraisal. Immun Ageing 7:7. https://doi.org/10.1186/ 1742-4933-7-7

Orrhage K, Brismar B, Nord CE (1994) Effect of supplements with Bifidobacterium longum and Lactobacillus acidophilus on the intestinal microbiota during administration of clindamycin. Microbial Ecol Health Dis 7:17-25. https://doi.org/10.3109/ 08910609409141570

Ott SJ, Musfeldt M, Wenderoth DF, Hampe J, Brant O, Fölsch UR, Timmis KN, Schreiber S (2004) Reduction in diversity of the colonic mucosa associated bacterial microflora in patients with active inflammatory bowel disease. Gut 53:685-693. https://doi.org/10. 1136/gut.2003.025403

Ouwehand AC, Salminen S, Isolauri E (2002) Probiotics: an overview of beneficial effects. Antonie Van Leeuwenhoek 82:279-289. https:// doi.org/10.1023/A:1020620607611
Panigrahi P, Parida S, Nanda NC, Satpathy R, Pradhan L, Chandel DS, Baccaglini L, Mohapatra A, Mohapatra SS, Misra PR, Chaudhry R, Chen HH, Johnson JA, Morris JG, Paneth N, Gewolb IH (2017) A randomized synbiotic trial to prevent sepsis among infants in rural India. Nature 548:407-412. https://doi.org/10.1038/nature23480

Papadimitriou K, Zoumpopoulou G, Foligné B, Alexandraki V, Kazou M, Pot B, Tsakalidou E (2015) Discovering probiotic microorganisms: in vitro, in vivo, genetic and omics approaches. Front Microbiol 6:58. https://doi.org/10.3389/fmicb.2015.00058

Parvez S, Malik KA, Ah Kang S, Kim HY (2006) Probiotics and their fermented food products are beneficial for health. J Appl Microbiol 100:1171-1185. https://doi.org/10.1111/j.1365-2672.2006.02963.x

Pascal V, Pozuelo M, Borruel N, Casellas F, Campos D, Santiago A, Martinez X, Varela E, Sarrabayrouse G, Machiels K, Vermeire S (2017) A microbial signature for Crohn's disease. Gut 66:813-822. https://doi.org/10.1136/gutjnl-2016-313235

Pathmakanthan S, Walsh M, Bengmark S (2002) Efficacy and tolerability treating acute distal ulcerative colitis with synbiotic enemas: a pilot trial (abstract). United European Gastroenterology Week, Geneva, p 190

Perdigon G, Alvarez S, Nader ME, Macias DE, Roux ME, de Ruiz Holgado AP (1990) The oral administration of lactic acid bacteria increase the mucosal intestinal immunity in response to enteropathogens. J Food Prot 53:404-410. https://doi.org/10.4315/ 0362-028X-53.5.404

Perez-Conesa D, López G, Abellán P, Ros G (2006) Bioavailability of calcium, magnesium and phosphorus in rats fed probiotic, prebiotic and synbiotic powder follow-up infant formulas and their effect on physiological and nutritional parameters. J Sci Food Agric 86:23272336. https://doi.org/10.1002/jsfa.2618

Perrin S, Warchol M, Grill JP, Schneider F (2001) Fermentations of fructo-oligosaccharides and their components by Bifidobacterium infantis ATCC 15697 on batch culture in semi-synthetic medium. J Appl Microbiol 90:859-865. https://doi.org/10.1046/j.1365-2672. 2001.01317.x

Petrova P, Ivanov I, Tsigoriyna L, Valcheva N, Vasileva E, ParvanovaMancheva T, Arsov A, Petrov K (2021) Traditional Bulgarian dairy products: ethnic foods with health benefits. Microorganisms 9:480. https://doi.org/10.3390/microorganisms 9030480

Prestinaci F, Pezzotti P, Pantosti A (2015) Antimicrobial resistance: a global multifaceted phenomenon. Pathog Glob Health 109:309318. https://doi.org/10.1179/2047773215Y.0000000030

Prosberg M, Bendtsen F, Vind I, Petersen AM, Gluud LL (2016) The association between the gut microbiota and the inflammatory bowel disease activity: a systematic review and meta-analysis. Scand J Gastroenterol 51:407-1415. https://doi.org/10.1080/00365521. 2016.1216587

Reddy BS, Rivenson A (1993) Inhibitory effect of Bifidobacterium longum on colon, mammary, and liver carcinogenesis induced by 2-amino-3-methylimidazo[4,5-f]quinoline, a food mutagen. Cancer Res 53:3914-3918

Roberfroid M, Gibson GR, Delzenne N (1993) The biochemistry of oligofructose, a nondigestible fiber: an approach to calculate its caloric value. Nutr Rev 51:137-146. https://doi.org/10.1111/j.17534887.1993.tb03090.x

Roberfroid MB (2000) Prebiotics and probiotics: are they functional foods? Am J Clin Nutr 71:1682S-1687S. https://doi.org/10.1093/ ajen/71.6.1682S

Safavi M, Farajian S, Kelishadi R, Mirlohi M, Hashemipour M (2013) The effects of synbiotic supplementation on some cardio-metabolic risk factors in overweight and obese children: a randomized triplemasked controlled trial. Int J Food Sci Nutr 64:687-693. https://doi. org/10.3109/09637486.2013.775224

Sanchez M, Darimont C, Drapeau V, Emady-Azar S, Lepage M, Rezzonico E, Ngom-Bru C, Berger B, Philippe L, AmmonZuffrey C, Leone P, Chevrier G, St-Amand E, Marette A, Doré J, Tremblay A (2014) Effect of Lactobacillus rhamnosus 
CGMCC1.3724 supplementation on weight loss and maintenance in obese men and women. Br J Nutr 111:1507-1519. https://doi.org/ 10.1017/S0007114513003875

Sarowska J, Choroszy-Krol I, Regulska-Ilow B, Frej-Mądrzak M, JamaKmiecik A (2013) The therapeutic effect of probiotic bacteria on gastrointestinal diseases. Adv Clin Exp Med 22:759-766

Schiffrin EJ, Rochat F, Link-Amster H, Aeschlimann JM, DonnetHughes A (1995) Immunomodulation of human blood cells following the ingestion of lactic acid bacteria. J Dairy Sci 78:491-497. https://doi.org/10.3168/jds.S0022-0302(95)76659-0

Schultz M, Sartor RB (2000) Probiotics and inflammatory bowel diseases. Am J Gastroenterol 95:S19-S21. https://doi.org/10.1016/ S0002-9270(99)00812-6

Semjonovs SP, Marauska M, Linde R, Grube M, Zikmanis P, Bekers M (2004) Development of Bifidobacterium lactis Bb12 on $\beta-(2,6)-$ linked fructan-containing substrate. Eng Life Sci 4:433-437. https://doi.org/10.1002/elsc.200420043

Shahani KM, Chandan RC (1979) Nutritional and healthful aspects of cultured and culture-containing dairy foods. J Dairy Sci 62:16851694. https://doi.org/10.3168/jds.S0022-0302(79)83481-5

Sharma M, Shukla G (2016) Metabiotics: one step ahead of probiotics; an insight into mechanisms involved in anticancerous effect in colorectal cancer. Front Microbiol 7:1940. https://doi.org/10.3389/fmicb. 2016.01940

Sharma P, Kaur S, Chadha BS, Kaur R, Kaur M, Kaur S (2021) Anticancer and antimicrobial potential of enterocin 12a from Enterococcus faecium. BMC Microbiol 21:39. https://doi.org/10. 1186/s12866-021-02086-5

Sheih YH, Chiang BL, Wang LH, Liao CK, Gill HS (2001) Systemic immunity-enhancing effects in healthy subjects following dietary consumption of the lactic acid bacterium Lactobacillus rhamnosus HN001. J Am Coll Nutr 20:149-156. https://doi.org/10.1080/ 07315724.2001 .10719027

Sheil B, Shanahan F, O'Mahony L (2007) Probiotic effects on inflammatory bowel disease. J Nutr 137:819S-824S. https://doi.org/10.1093/ jn/137.3.819S

Sheoran P, Tiwari SK (2019) Enterocin LD3 from Enterococcus hirae LD3 causing efflux of intracellular ions and UV absorbing materials in Gram-negative bacteria. J Appl Microbiol 126:1059-1069. https://doi.org/10.1111/jam.14203

Sheoran P, Tiwari SK (2020)Synergistically-acting enterocin LD3 and plantaricin LD4 against Gram-positive and Gram-negative pathogenic bacteria. Probiotics Antimicrob Proteins 13:542-554. https:// doi.org/10.1007/s12602-020-09708-w

Shim YH, Lee SJ, Lee JW (2016) Antimicrobial activity of Lactobacillus strains against uropathogens. Pediatr Inter 58:1009-1013. https:// doi.org/10.1111/ped.12949

Shin HS, Lee JH, Pestka JJ, Ustunol Z (2000) Growth and viability of commercial Bifidobacterium spp. in skim milk containing oligosaccharides and inulin. J Food Sci 65:884-887. https://doi.org/10.1111/ j.1365-2621.2000.tb13605.x

Sicherer SH, Muñoz-Furlong A, Sampson HA (2004) Prevalence of seafood allergy in the United States determined by a random telephone survey. J Allergy Clin Immunol 114:159-165. https://doi.org/10. 1016/j.jaci.2004.04.018

Siitonen S, Vapaatalo H, Salminen S, Gordin A, Saxelin M, Wikberg R, Kirkkola AL (1990) Effect of Lactobacillus GG yoghurt in prevention of antibiotic associated diarrhoea. Ann Med 22:57-59. https:// doi.org/10.3109/07853899009147243

Silva DR, OrlandiSardi JC, Pitangui NS, MagriRoque S, Barbosa da Silva AC, Rosalen PL (2020) Probiotics as an alternative antimicrobial therapy: current reality and future directions. J Funct Foods 73: 104080. https://doi.org/10.1016/j.jff.2020.104080

Singh K, Rao A (2021) Probiotics: a potential immunomodulator in COVID-19 infection management. Nutr Res 87:1-12. https://doi. org/10.1016/j.nutres.2020.12.014
Šmid A, Strniša L, Bajc K, Vujić-Podlipec D, Matijašić BB, Rogelj I (2016) Randomized clinical trial: the effect of fermented milk with the probiotic cultures Lactobacillus acidophilus La-5® and Bifidobacterium BB-12® and Beneo dietary fibres on healthrelated quality of life and the symptoms of irritable bowel syndrome in adults. J Funct Foods 24:549-557. https://doi.org/10.1016/j.jff. 2016.04.031

Sokol H, Pigneur B, Watterlot L, Lakhdari O, Bermúdez-Humarán LG, Gratadoux JJ, Blugeon S, Bridonneau C, Furet JP, Corthier G, Grangette C (2008)Faecalibacterium prausnitzii is an antiinflammatory commensal bacterium identified by gut microbiota analysis of Crohn disease patients. Proc Natl Acad Sci U S A 105: 16731-16736. https://doi.org/10.1073/pnas.0804812105

Somashekaraiah R, Mottawea W, Gunduraj A, Joshi U, Hammami R, Sreenivasa MY (2021) Probiotic and antifungal attributes of Levilactobacillus brevis MYSN105, isolated from an Indian traditional fermented food Pozha. Front Microbiol 12:696267. https:// doi.org/10.3389/fmicb.2021.696267

Starosila D, Rybalko S, Varbanetz L, Ivanskaya N, Sorokulova I (2017)Anti-influenza activity of a Bacillus subtilis probiotic strain. Antimicrob Agents Chemother 61:e00539-e617. https://doi.org/10. 1128/AAC.00539-17

Strobel S, Strid J (2002) Natural killer cells and aspects of intestinal immunity. In: Brostoff J, Challacombe SJ (eds) Food allergy and intolerance. Elsevier Science Limited, London, pp 117-126

Sutas Y, Hurme M, Isolauri E (1996)Down-regulation of anti-CD3 antibody-induced IL-4 production by bovine caseins hydrolysed with LactobacillusGG-derived enzymes. Scand J Immunol 43:687-689. https://doi.org/10.1046/j.1365-3083.1996.d01-258.x

Swanson KS, Gibson GR, Hutkins R, Reimer RA, Reid G, Verbeke K, Scott KP, Holscher HD, Azad MB, Delzenne NM, Sanders ME (2020) The International Scientific Association for Probiotics and Prebiotics (ISAPP) consensus statement on the definition and scope of synbiotics. Nat Rev Gastroenterol Hepatol 17:687-701. https:// doi.org/10.1038/s41575-020-0344-2

Tajadadi-Ebrahimi M, Bahmani F, Shakeri H, Hadaegh H, Hijijafari M, Abedi F, Asemi Z (2014) Effects of daily consumption of synbiotic bread on insulin metabolism and serum high-sensitivity C-reactive protein among diabetic patients: a double-blind, randomized, controlled clinical trial. Ann Nutr Metab 65:34-41. https://doi.org/10. $1159 / 000365153$

Takahashi K, Nishida A, Fujimoto T, Fujii M, Shioya M, Imaeda H, Inatomi O, Bamba S, Andoh A, Sugimoto M (2016) Reduced abundance of butyrate-producing bacteria species in the fecal microbial community in Crohn's disease. Digestion 93:59-65. https://doi.org/ $10.1159 / 000441768$

Taverniti V, Guglielmetti S (2011) The immunomodulatory properties of probiotic microorganisms beyond their viability (ghost probiotics: proposal of paraprobiotic concept). Genes Nutr 6:261-274. https:// doi.org/10.1007/s12263-011-0218-x

Taylor SL, Hefle SL (2005) Allergen control. Food. Sci Technol 59:40-43

Tharmaraj N, Shah NP (2009) Antimicrobial effects of probiotics against selected pathogenic and spoilage bacteria in cheese-based dips. Int Food Res J 16:261-276

Tiwari SK, Dicks LMT, Popov IV, Karaseva A, Ermakov AM, Suvorov A, Tagg JR, Weeks R, Chikindas ML (2020) Probiotics at war against viruses: what is missing from the picture? Front Microbiol 11:1877. https://doi.org/10.3389/fmicb.2020.01877

Tojo M, Oikawa T, Morokawa Y, Yamashita N, Iwata S, Satoh Y, Hanada J, Tanaka R (1987) The effects of Bifidobacterium breve administration on Campylobacter enteritis. Acta Aaediatr Jpn 29: 160-167. https://doi.org/10.1111/j.1442-200x.1987.tb00024.x

Trasande L, Shaffer RM, Sathyanarayana S (2018) Food additives and child health. Pediatrics 142:e20181410. https://doi.org/10.1542/ peds.2018-1410 
Tzounis X, Rodriguez-Mateos A, Vulevic J, Gibson GR, Kwik-Uribe C, Spencer JP (2011) Prebiotic evaluation of cocoa-derived flavanols in healthy humans by using a randomized, controlled, double-blind, crossover intervention study. Am J Clin Nutr 93:62-72. https:// doi.org/10.3945/ajcn.110.000075

Uhlig HH, Muise AM (2017) Clinical genomics in inflammatory bowel disease. Trends Genet 33:629-641. https://doi.org/10.1016/j.tig. 2017.06.008

Uhlig HH, Powrie F (2018) Translating immunology into therapeutic concepts for inflammatory bowel disease. Ann Rev Immunol 36:755781. https://doi.org/10.1146/annurev-immunol-042617-053055

Van der Meer R, Bovee-Oudenhoven IMJ (1998) Dietary modulation of intestinal bacterial infections. Int Dairy J 8:481-486. https://doi.org/ 10.1016/S0958-6946(98)00072-7

Van der Meulen R, Avonts L, De Vuyst L (2004) Short fractions of oligofructose are preferentially metabolized by Bifidobacterium animalis DN-173010. Appl Environ Microbiol 70:1923-1930. https://doi.org/10.1128/AEM.70.4. 1923-1930.2004

Van Laere KM, Hartemink R, Bosveld M, Schols HA, Voragen AG (2000) Fermentation of plant cell wall derived polysaccharides and their corresponding oligosaccharides by intestinal bacteria. J Agric Food Chem 48:1644-1652. https://doi. org $/ 10.1021 / \mathrm{jf} 990519 \mathrm{i}$

Vazquez MJ, Alonso JL, Domınguez H, Parajo JC (2000) Xylooligosaccharides: manufacture and applications. Trends Food Sci Technol 11:387-393. https://doi.org/10.1016/S0924-2244(01) 00031-0

Vergin F (1954)Anti- und Probiotika [Antibiotics and probiotics]. Hippokrates 25:116-119

Wang W, Chen L, Zhou R, Wang X, Song L, Huang S, Wang G, Xia B (2014) Increased proportions of Bifidobacterium and the Lactobacillus group and loss of butyrate-producing bacteria in inflammatory bowel disease. J Clin Microbiol 52:398-406. https:// doi.org/10.1128/JCM.01500-13

Wang W, Xin H, Fang X, Dou H, Liu F, Huang D, Han S, Fei G, Zhu L, Zha S, Zhang H (2017)Isomalto-oligosaccharides ameliorate visceral hyperalgesia with repair damage of ileal epithelial ultrastructure in rats. PLoS ONE 12:e0175276. https://doi.org/10.1371/journal.pone. 0175276

Wong VW, Won GL, Chim AM, Chu WC, Yeung DK, Li KC, Chan HL (2013) Treatment of nonalcoholic steatohepatitis with probiotics. A proof-of-concept study. Ann Hepatol 12:256-262

Yang SC, Chen JY, Shang HF, Cheng TY, Tsou SC, Chen JR (2005) Effect of synbiotics on intestinal microflora and digestive enzyme activities in rats. World J Gastroenterol 11:7413. https://doi.org/10. 3748/wjg.v11.i47.7413

Yen CH, Tseng YH, Kuo YW, Lee MC, Chen HL (2011)Longterm supplementation of isomalto-oligosaccharides improved colonic microflora profile, bowel function, and blood cholesterol levels in constipated elderly people-a placebo-controlled, diet-controlled trial. Nutrition 27:445-450. https:// doi.org/10.1016/j.nut.2010.05.012

Yoon JS, Sohn W, Lee OY, Lee SP, Lee KN, Jun DW, Lee HL, Yoon BC, Choi HS, Chung WS, Seo JG (2014) Effect of multispecies probiotics on irritable bowel syndrome: a randomized, double-blind, placebo-controlled trial. J Gastroenterol Hepatol 29:52-59. https:// doi.org/10.1111/jgh.12322

Zeng H, Xue Y, Peng T, Shao W (2007) Properties of xylanolytic enzyme system in bifidobacteria and their effects on the utilization of xylooligosaccharides. Food Chem 101:1172-1177. https://doi.org/ 10.1016/j.foodchem.2006.03.019

Publisher's note Springer Nature remains neutral with regard to jurisdictional claims in published maps and institutional affiliations. 